\title{
Lipids as trophic markers in Antarctic krill. II. Lipid composition of the body and digestive gland of Euphausia superba in controlled conditions
}

\author{
Frédéric Alonzo ${ }^{1,2,3,5, *}$, Patti Virtue ${ }^{1}$, Stephen Nicol $^{2}$, Peter D. Nichols ${ }^{3,4}$ \\ ${ }^{1}$ Institute of Antarctic and Southern Ocean Studies, University of Tasmania, Private Bag 77, Hobart, Tasmania 7001, Australia \\ ${ }^{2}$ Australian Antarctic Division, Channel Highway, Kingston, Tasmania 7050, Australia \\ ${ }^{3}$ CSIRO Marine Research, Castray Esplanade, GPO Box 1538, Hobart, Tasmania 7001, Australia \\ ${ }^{4}$ Antarctic Cooperative Research Centre, University of Tasmania, GPO Box 252-77, Hobart, Tasmania 7001, Australia \\ ${ }^{5}$ Present address: Institut de Radioprotection et de Sûreté Nucléaire, Centre de Cadarache, BP 3, \\ 13115 Saint-Paul-Lez-Durance cedex, France
}

\begin{abstract}
To examine the potential of lipids as dietary markers in Euphausia superba Dana, juvenile krill were fed 4 phytoplankton diets (diatoms, cryptomonads, dinoflagellates and thraustochytrids over a range of food concentrations) and 2 species of zooplankton (rotifers and Artemia sp.) for $20 \mathrm{~d}$. Lipid content, lipid class and fatty acid (FA) composition were analysed for whole krill and digestive glands (DG). Changes detected in whole krill were almost entirely associated with the lipid variability observed in DG. With marked diet-induced changes, DG lipids were the major repository for the trophic signal in krill. DG lipid content increased in krill fed on phytoplankton due to the accumulation of polar lipid (0.5 mg per DG) and triacylglycerol (up to $1.7 \mathrm{mg}$ per DG). Herbivorous diets induced distinct FA signatures in the DG, characterised by higher proportions of: $16: 1 \omega 7$ and 20:5 $\omega 3$

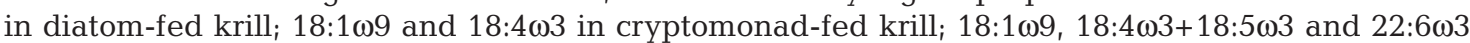
in dinoflagellate-fed krill; and 14:0 and 22:603 in thraustochytrid-fed krill. Dietary FA markers increased in relative proportion (\% total FA) in the DG with increasing concentration of each particular food. Krill fed rotifers or Artemia sp. showed relatively low DG lipid content, with only

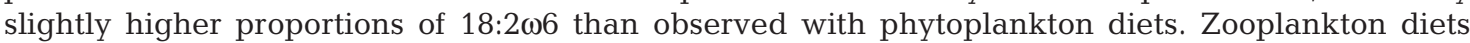
induced no significant difference in FA composition in relation to the species of zooplankton used as prey or to the algal type consumed by these prey.
\end{abstract}

KEY WORDS: Euphausia superba · Antarctic krill · Lipid class · Fatty acid · Trophic marker . Digestive gland

\section{INTRODUCTION}

Antarctic krill Euphausia superba (hereafter 'krill') is a key component of the Southern Ocean ecosystem, both as a widespread and abundant species which can dominate the zooplankton community (Ross \& Quetin 1988, Miller \& Hampton 1989) and as a major food item for many vertebrates (El-Sayed 1985). Due to this central role in the food web, the feeding ecology of Antarctic krill has been studied in detail over the past 3 decades. Based on methods including in vitro incu- bations, stable isotope analysis and gut content analysis, E. superba is recognised as an efficient grazer which feeds predominantly on phytoplankton (Antezana et al. 1982, Hopkins et al. 1993, Quetin et al. 1994, Frazer 1996, Pakhomov et al. 1997), although the species is also able to prey upon protozoans and larger zooplankton organisms, including copepods (Clarke 1980, Price et al. 1988, Huntley et al. 1994, Atkinson \& Snÿder 1997, Perissinotto et al. 2000, Hernandez-León et al. 2001, Atkinson et al. 2002). The relative contribution of carnivory and herbivory to the energy budget of 
krill remains unknown and has been shown to vary with geographical locations, season and diel cycle. Although morphologically adapted for eating phytoplankton (Nemoto 1967, Kils 1981), krill can feed efficiently on whatever food is available (Schnack 1985). The algal food source of krill is patchy and greatly variable, and resorting to predation is possibly part of a strategy which ensures krill survival when primary production is low.

Among major approaches, lipid analysis has been used increasingly to describe feeding habits and past nutritional condition of Antarctic krill from the field. Regional differences in triacylglycerol (TAG) content and fatty acid (FA) composition of Euphausia superba have been attributed to changes in diet (Mayzaud 1997, Cripps et al. 1999, Phleger et al. 2002). The herbivorous behaviour of E. superba was suggested by the resemblances in fatty acid compositions of phytoplankton and krill in the Ross Sea (Bottino 1974). However, the value of FA as trophic markers in krill remains controversial. Controlled laboratory experiments suggest that FA profiles of the species provide information on food sources (Virtue et al. 1993a,b, Cripps \& Atkinson 2000), although changes in FA composition with changing diet can be very small or even not detectable in E. superba from the field or maintained in the laboratory (Cripps \& Hill 1998, Stübing et al. 2003). In copepods, laboratory evidence has demonstrated that controlled diets induce changes in lipid class and FA composition (Hakånson 1984, Graeve et al. 1994). Such experiments are required in Antarctic krill, as this species shows distinct lipid metabolism, with storage based on TAG and polar lipids (PL) instead of wax esters (Lee et al. 1971, Clarke 1980).

In the wild, factors such as sex and maturity stages influence lipid composition in Euphausia superba (Clarke 1980, Kolokowska 1991, Pond et al. 1995, Virtue et al. 1996). These observations suggest that the physiological function of lipids in particular organs may interfere with trophic information. This problem might come from past studies analysing lipids in whole krill, therefore including organs such as the ovary, where variability is unequivocally related to reproduction activity (Mayzaud et al. 1998). Focusing lipid analyses on parts of organisms, such as digestive glands (DG, also referred to as hepatopancreas), is of potential interest. The DG is one of the main sites for lipid synthesis and storage in crustaceans (Teshima \& Kanazawa 1980, Dall et al. 1992), and has shown large variability in lipid composition with feeding conditions (Virtue et al. 1993a, Alonzo et al. 2003). Our present aim was to investigate the factors which govern the influence of diet on the FA composition of E. superba. We compared diet-induced changes in lipids between DG and whole krill, and examined the effect of feeding rate using various phytoplankton diets. Further, we attempted to define signatures of carnivorous diets using zooplankton as prey and to evaluate whether phytoplankton consumed by these prey may influence the lipid composition of krill at the second trophic level.

\section{MATERIALS AND METHODS}

Krill collection. Euphausia superba were collected in March 2001 in the Southern Ocean $\left(65^{\circ} 05^{\prime} \mathrm{S}\right.$, $109^{\circ} 42^{\prime} \mathrm{E}$ ), at the ice edge and in the top $30 \mathrm{~m}$ of the water column, using a Rectangular Midwater Trawl net (RMT 8). Krill were subsequently maintained at $0^{\circ} \mathrm{C}$ on board the RV 'Aurora Australis', transferred to the aquarium facilities at the Australian Antarctic Division (Kingston, Tasmania) and fed every week on the diatom Phaeodactylum tricornutum. Due to high post-capture mortality, experiments were run after an acclimation period of 2 mo.

Food source. Krill were fed 4 herbivorous and 2 carnivorous diets, obtained from:

- Axenic cultures in exponential growth of the diatom Phaeodactylum tricornutum, the Antarctic cryptomonad Geminogera cryophyllum and the Antarctic dinoflagellate Polarella glacialis, grown at $5^{\circ} \mathrm{C}$ under a $12 \mathrm{~h}$ light:12 h dark cycle in $\mathrm{f} / 2$ medium (Guillard \& Ryther 1962).

- Spray-dried cells of the thraustochytrid Schyzochitrium sp. (Algamac-2000 ${ }^{\circledR}$ ), purchased from Aquafauna Bio-marine.

- The rotifer Brachionus plicatilis and the branchiopod Artemia sp., purchased from the Tasmanian Aquaculture and Fisheries Institute and enriched on diatoms, cryptomonads or thraustochytrids. Enrichment was done overnight using $250 \mathrm{ml}$ of phytoplankton culture made up to $1 \mathrm{l}$ in filtered seawater with a density of $500 \mathrm{~B}$. plicatilis $\mathrm{ml}^{-1}$ and 250 Artemia $\mathrm{ml}^{-1}$. Enrichment temperatures were 22 and $27^{\circ} \mathrm{C}$ for B. plicatilis and Artemia respectively. Animals of both species showed guts full with food after a night feeding. Zooplankton were rinsed on a $50 \mu \mathrm{m}$ mesh to remove phytoplankton before use.

Food quality. Dry weight, protein and lipid content were measured for all feeds. Phytoplankton and zooplankton were filtered on precombusted Whatman GF/C filters. Dry weight was measured after filters were rinsed with $4.5 \%$ ammonium formate and dried at $60^{\circ} \mathrm{C}$ for $2 \mathrm{~d}$. Triplicate protein extracts were obtained in $0.5 \mathrm{~N} \mathrm{NaOH}$ and quantified using a bicinchoninic acid (BCA) kit for protein assays (Pierce Biotechnology) with bovine serum albumin as standard. For lipid quantification, filters were stored at $-80^{\circ} \mathrm{C}$ until analysis.

Food quantity. Phytoplankton diets were diluted with $0.45 \mu \mathrm{m}$ filtered seawater to achieve 3 protein 
concentrations: 'low' $\left(0.2 \mathrm{mg} \mathrm{l}^{-1}\right)$, 'medium' $\left(0.6 \mathrm{mg} \mathrm{l}^{-1}\right)$ and 'high' (2.0 $\left.\mathrm{mg} \mathrm{l}^{-1}\right)$. An extra 'saturating' level (4.0 $\mathrm{mg} \mathrm{l}^{-1}$ ) was provided with thraustochytrids. Krill were fed excess zooplankton densities: 15000 rotifers $\mathrm{l}^{-1}$ (5.7 mg protein $\mathrm{l}^{-1}$ ) and 5000 Artemia $\mathrm{l}^{-1}$ (5.2 mg protein $\mathrm{l}^{-1}$ ).

Feeding conditions. Juvenile krill of approximately similar size were used to avoid the potential bias in lipid metabolism associated with reproduction. Krill were maintained at $0^{\circ} \mathrm{C}$, at a density of 3 animals per 21 jar. Six jars (for a total of 18 krill) were run in each treatment. Food was changed every 24 h. Faecal pellet production and krill ingestion were measured every second day. Krill mortality remained well below $5 \% \mathrm{~d}^{-1}$ in all experiments (average rate of $1.9 \% \mathrm{~d}^{-1}$ ). Samples of 12 krill per treatment were collected after $20 \mathrm{~d}$ of feeding, and frozen immediately in liquid nitrogen. A sample of 12 krill was also collected at the beginning of the experiments on Day 0 (hereafter 'initial condition').

Faecal pellet production. Jar contents were sieved through a $50 \mu \mathrm{m}$ mesh to separate krill faecal pellets from remaining phytoplankton. Faecal pellets were collected on Whatman GF/C filters. Dry weight was measured after filters were rinsed with $4.5 \%$ ammonium formate and dried at $60^{\circ} \mathrm{C}$ for $2 \mathrm{~d}$. Faecal pellet production was not measured in the jars incubated with zooplankton, as krill faeces could not be separated from remaining rotifers or Artemia.

Mean ingestion. After faecal pellets were removed, remaining food concentration [Food] $]_{24}$ at time $t=24 \mathrm{~h}$ was measured by microscope counts (diatoms, cryptomonads, dinoflagellates and zooplankton) or gravimetry (dried thraustochytrids). Mean protein concentration, Prot $\left(\mathrm{mg} \mathrm{l}^{-1}\right)$, was calculated using Frost's equation (1972):

$$
\text { Prot }=C_{\text {Prot }} \times \frac{[\text { Food }]_{24}-[\text { Food }]_{0}}{(k-g) \times t}
$$

where $[\text { Food }]_{0}$ is the food concentration in the experiment jar at time $t=0, C_{\text {Prot }}$ is the protein content of the feed, $k$ is the growth constant measured from changes in algal densities in jars without krill for $24 \mathrm{~h}$ ( $k=0$ for the dried thraustochytrids) and $g$ is the krill grazing coefficient:

$$
k=\frac{\ln \left(\frac{[\text { Food }]_{24}}{[\text { Food }]_{0}}\right)}{t} \text { and } g=k-\frac{\ln \left(\frac{[\text { Food }]_{24}}{[\text { Food }]_{0}}\right)}{t}
$$

Similarly, a mortality coefficient $m$ (instead of $k$ ) was measured for rotifers and Artemia maintained at $0^{\circ} \mathrm{C}$ in jars without krill for $24 \mathrm{~h}$.

Mean krill ingestions $I_{\text {Prot }}\left(\mathrm{mg}\right.$ protein $\left.\mathrm{d}^{-1} \mathrm{krill}^{-1}\right)$ and $I_{\text {Lip }}$ (mg lipids $\mathrm{d}^{-1} \mathrm{krill}^{-1}$ ) were calculated in the jars using the following equations:

$$
\begin{gathered}
I_{\text {Prot }}=C_{\text {Prot }} \times \frac{[\text { Food }]_{24}-[\text { Food }]_{0}}{N \times t} \times V \\
I_{\text {Lip }}=R_{\text {Lip } / \text { Prot }} \times I_{\text {Prot }}
\end{gathered}
$$

where $N$ is the number of krill per jar, $V$ is the volume of the jars and $R_{\mathrm{Lip} / \mathrm{Prot}}$ is the lipid:protein ratio of the feed.

Lipid analyses. Whole krill wet weights were measured and entire DG were dissected out. Remaining fractions (RF, krill without their DG) were weighed and analysed in 9 feeding treatments. DG were weighed and analysed in all of the 19 feeding treatments. Three replicate analyses were performed per treatment, using a total of 9 DG (3 batched DG per analysis) or 3 RF (1 RF per analysis). The lipid composition of whole krill was calculated using lipid class and fatty acid content measured in the different parts of the animals.

Full details on lipid analyses are provided elsewhere (Bakes et al. 1995, Nichols et al. 1998). Briefly, samples were immediately ground and extracted using a single phase Bligh \& Dyer (1959) procedure. Lipid extracts were weighed and stored at $-80^{\circ} \mathrm{C}$. Aliquots of the lipid were analysed by Iatroscan TLC-FID (thin layer chromatography coupled with flame ionisation detection) to determine lipid class composition. FA profiles were obtained by capillary GC and GC-MS (gas chromatography coupled with mass spectrometry) analysis following transmethylation of an aliquot of the extracted lipids.

Data analysis. Differences between samples were tested using ANOVA (Sokal \& Rohlf 1981). The alpha level was 0.05. Principal component analysis (PCA; Wold 1987) was used to examine FA composition (mg FA g ${ }^{-1}$ of lipid) of the DG. This analysis included DG FA profiles from this study and from Alonzo et al. (2005, this volume) and was conducted using SPAD 3.5 (DECISIA).

\section{RESULTS}

\section{Food quality}

Markedly different proximate compositions were observed among the various phytoplankton (Table 1), with protein proportion (as \% of dry weight, DW) ranging from $12 \%$ in diatoms to $55 \%$ in cryptomonads. In comparison, zooplankton were rich in protein, with the proportion ranging from 53\% in thraustochytridenriched Artemia to $84 \%$ in thraustochytrid-enriched rotifers. The lipid:protein ratio varied from 0.12 to 1.10 in phytoplankton. Zooplankton showed lower ratios than algae: 0.07 to 0.09 in rotifers and 0.10 to 0.21 in Artemia. Consequently, as feeding conditions were 
Table 1. Food quality: Protein, lipids (percent of DW), polar lipids (percent total lipids) and fatty acid composition (percent of total FA) of phytoplankton and zooplankton used as food. In dinoflagellates, 18:4 3 was present as a minor co-eluting component with 18:5 13 , making these $2 \mathrm{FA}$ difficult to quantify separately. Crypto $=$ cryptomonads; Dino $=$ dinoflagellates; Thrausto $=$ thraustochytrids. nd $=$ not determined

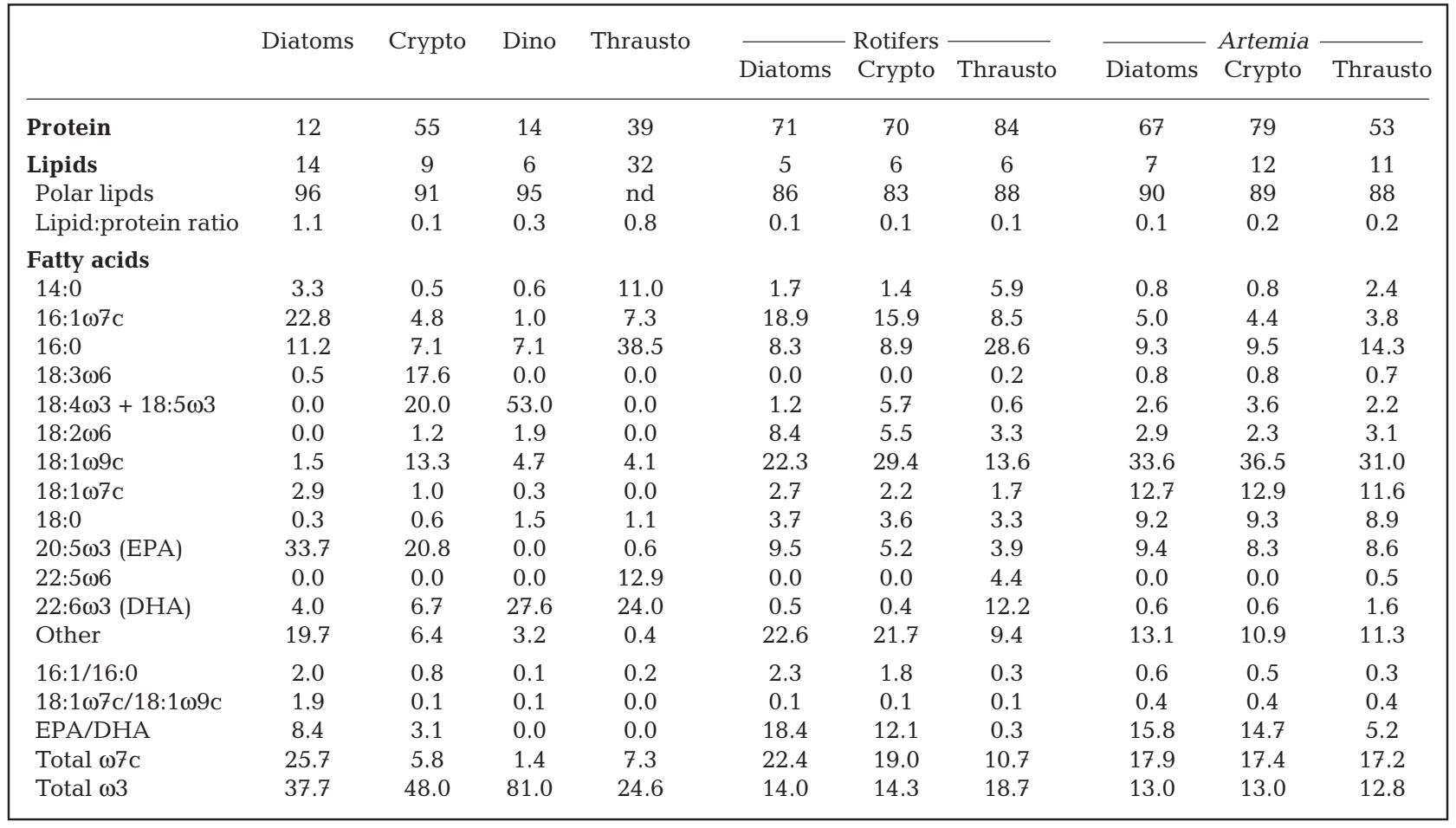

based on protein concentration, equivalent feeding levels reflected different total lipid concentrations among food sources.

Lipids were dominated by PL in all diets, accounting for 83 to $90 \%$ of total lipids in zooplankton and up to 91 to $96 \%$ in phytoplankton (Table 1). FA composition showed large differences among phytoplankton and was dominated by: 20:5 $\omega 3$ (hereafter 'EPA' for eicosapentaenoic acid), 16:1 107 and 16:0 in diatoms; EPA, $18: 4 \omega 3,18: 3 \omega 6$ and $18: 1 \omega 9$ in cryptomonads; $18: 5 \omega 3$ and 22:6 13 (hereafter 'DHA' for docosahexaenoic acid) in dinoflagellates; 16:0, DHA, 22:5 thraustochytrids.

Zooplankton FA were dominated by 18:1 $\omega 9$, accounting for 13.6 to $29.4 \%$ of total FA in rotifers and 31.0 to $36.5 \%$ in Artemia (Table 1). Other major FA included 16:0 in both species, 16:1 107 in rotifers and 18:1 107 in Artemia. Enrichment treatments induced only small changes in Artemia, whereas much greater differences were observed in rotifer FA composition. The proportions of 16:0 and DHA were higher in thraustochytrid-enriched rotifers (28.6 and $12.2 \%$ of total FA respectively) than in other rotifers (8.6 and $0.5 \%$ respectively). Rotifers showed the highest proportion of $16: 1 \omega 7(18.9 \%)$ and 18:1 $\omega 9$ (29.4\%) when enriched respectively on diatoms and on cryptomonads.

\section{Nutrition}

Krill consumed the diet and produced faecal pellets in all feeding conditions. Ingestion and defecation rates varied among feeding treatments with both concentration and source of food (Table 2). Protein ingestion rates were approximately equal among the phytoplankton diets for a given concentration of food, accounting for 0.06 to $0.09 \mathrm{mg} \mathrm{d}^{-1} \mathrm{krill}^{-1}$ at low concentrations and 0.32 to $0.81 \mathrm{mg} \mathrm{d}^{-1} \mathrm{krill}^{-1}$ at high concentrations. Due to a low lipid:protein ratio, cryptomonad diets induced relatively smaller lipid ingestion rates (0.01 and $0.06 \mathrm{mg} \mathrm{d}^{-1} \mathrm{krill}^{-1}$ at low and high concentrations, respectively) than were observed with other phytoplankton ( 0.03 to 0.09 and 0.25 to $0.57 \mathrm{mg} \mathrm{d}^{-1} \mathrm{krill}^{-1}$ ). Zooplankton diets induced relatively high protein ingestion rates compared to the phytoplankton diets ( 0.33 to $1.34 \mathrm{mg} \mathrm{d}^{-1} \mathrm{krill}^{-1}$ ). Lipid ingestion rates varied within the same range of values as those observed with phytoplankton (0.05 to $0.27 \mathrm{mg} \mathrm{d}^{-1} \mathrm{krill}^{-1}$ ).

\section{Lipid content}

Body wet weight (WW) was equivalent among krill exposed to different feeding conditions. Lipid content of whole krill (as $\mathrm{mg} \mathrm{g}^{-1} \mathrm{WW}$, Table 3) varied sig- 
Table 2. Euphausia superba fed phytoplankton and zooplankton. Mean protein concentration in the experimental jars, protein and lipid ingestion, and faecal pellet production in relation to source and concentration of food. Data are mean $\pm \mathrm{SD}(\mathrm{N}=10) . \mathrm{nd}=$ not determined

\begin{tabular}{|c|c|c|c|c|}
\hline Diet & $\begin{array}{l}\text { Protein } \\
\left(\mathrm{mg} \mathrm{l}^{-1}\right)\end{array}$ & $\begin{array}{l}\text { Ingestion }(\mathrm{m} \\
\text { Protein }\end{array}$ & $\begin{array}{l}\mathrm{g} \mathrm{d}^{-1} \mathrm{krill}^{-1} \text { ) } \\
\text { Lipids }\end{array}$ & $\begin{array}{c}\text { Faecal pellets } \\
\text { (mg DW } \\
\left.\mathrm{d}^{-1} \mathrm{krill}^{-1}\right)\end{array}$ \\
\hline \multicolumn{5}{|l|}{ Phytoplankton } \\
\hline \multicolumn{5}{|l|}{ Diatoms } \\
\hline Low & $0.12 \pm 0.03$ & $0.08 \pm 0.02$ & $0.09 \pm 0.03$ & $0.18 \pm 0.11$ \\
\hline Medium & $0.49 \pm 0.04$ & $0.14 \pm 0.05$ & $0.15 \pm 0.05$ & $0.34 \pm 0.23$ \\
\hline High & $1.75 \pm 0.08$ & $0.32 \pm 0.10$ & $0.35 \pm 0.11$ & $0.36 \pm 0.21$ \\
\hline \multicolumn{5}{|l|}{ Cryptomonads } \\
\hline Low & $0.14 \pm 0.02$ & $0.06 \pm 0.02$ & $0.01 \pm 0.00$ & $0.07 \pm 0.03$ \\
\hline Medium & $0.35 \pm 0.04$ & $0.28 \pm 0.03$ & $0.03 \pm 0.00$ & $0.22 \pm 0.10$ \\
\hline High & $1.58 \pm 0.12$ & $0.51 \pm 0.13$ & $0.06 \pm 0.02$ & $0.46 \pm 0.27$ \\
\hline \multicolumn{5}{|l|}{ Dinoflagellates } \\
\hline Low & $0.12 \pm 0.03$ & $0.09 \pm 0.03$ & $0.03 \pm 0.01$ & $0.10 \pm 0.06$ \\
\hline High & $1.26 \pm 0.34$ & $0.81 \pm 0.29$ & $0.25 \pm 0.09$ & $0.21 \pm 0.13$ \\
\hline \multicolumn{5}{|l|}{ Thraustochytrids } \\
\hline Low & $0.14 \pm 0.03$ & $0.07 \pm 0.03$ & $0.05 \pm 0.03$ & $0.05 \pm 0.04$ \\
\hline Medium & $0.35 \pm 0.05$ & $0.28 \pm 0.04$ & $0.23 \pm 0.03$ & $0.05 \pm 0.03$ \\
\hline High & $1.41 \pm 0.10$ & $0.70 \pm 0.10$ & $0.57 \pm 0.08$ & $0.13 \pm 0.09$ \\
\hline Saturating & $2.70 \pm 0.23$ & $1.52 \pm 0.23$ & $1.24 \pm 0.19$ & $0.19 \pm 0.11$ \\
\hline \multicolumn{5}{|l|}{ Zooplankton } \\
\hline \multicolumn{5}{|l|}{ Rotifers } \\
\hline Diatoms & $5.54 \pm 1.51$ & $0.82 \pm 0.19$ & $0.06 \pm 0.01$ & nd \\
\hline Cryptomonads & $4.40 \pm 1.38$ & $1.05 \pm 0.44$ & $0.09 \pm 0.04$ & nd \\
\hline Thraustochytrids & $5.07 \pm 1.62$ & $0.75 \pm 0.28$ & $0.05 \pm 0.02$ & nd \\
\hline \multicolumn{5}{|l|}{ Artemia } \\
\hline Diatoms & $4.68 \pm 1.54$ & $0.33 \pm 0.21$ & $0.03 \pm 0.02$ & nd \\
\hline Cryptomonads & $4.70 \pm 1.25$ & $1.12 \pm 0.20$ & $0.17 \pm 0.03$ & nd \\
\hline Thraustochytrids & $3.92 \pm 1.37$ & $1.34 \pm 0.29$ & $0.27 \pm 0.06$ & nd \\
\hline
\end{tabular}

nificantly between the different treatments $(\mathrm{N}=27$, $\mathrm{p}=0.007$ ). However, this variability was entirely associated with changes in the DG. Lipid content of the RF did not show significant differences in relation to diet when DG were excluded ( $\mathrm{N}=27, \mathrm{p}=0.15)$, whereas
DG wet weight and lipid content showed significant differences in relation to both the source and level of food (Table 4). Krill fed on cryptomonads and on low and medium levels of diatoms showed the highest DG lipid content (2.0 to $4.5 \mathrm{mg}$ $\mathrm{g}^{-1}$ body WW). With these diets, lipid accumulation was 1.5- to 2-fold higher at the low food levels compared to the high food levels. Opposite trends were observed in krill fed on dinoflagellates and thraustochytrids, with higher DG lipid content at high and saturating food levels (1.4 to $1.5 \mathrm{mg} \mathrm{g}^{-1}$ body WW) than at low food levels (1.0 to $1.4 \mathrm{mg} \mathrm{g}^{-1}$ body WW). The DG similarly showed intermediate amounts of total lipid in krill fed on rotifers and Artemia sp. (1.3 to $1.5 \mathrm{mg} \mathrm{g}^{-1}$ body WW), when the zooplankton prey were enriched on thraustochytrids. Lowest DG lipid content $\left(\leq 1.0 \mathrm{mg} \mathrm{g}^{-1}\right.$ body WW) was observed in krill fed on other zooplankton diets (rotifer and Artemia sp. enriched on diatoms or thraustochytrids) or on high levels of diatoms.

\section{Lipid class composition}

Low levels of free fatty acids showed that lipids had not degraded at the time of analysis. Changes in lipid class composition showed quite different patterns in DG and RF. Although the amounts of TAG and PL in the RF were significantly related to total lipid (Fig. 1), the relative proportions did not significantly differ in relation to total lipids $(\mathrm{N}=27, \mathrm{p}=0.86)$, suggesting that these

Table 3. Euphausia superba fed phytoplankton and zooplankton. Wet weight (WW), lipid content and lipid class composition of whole krill in relation to source and concentration of food. Data are mean $\pm \mathrm{SD}(\mathrm{N}=3)$

\begin{tabular}{|c|c|c|c|c|c|}
\hline \multirow[t]{2}{*}{ Diet } & \multirow{2}{*}{$\begin{array}{l}\text { Wet weight } \\
(\mathrm{mg})\end{array}$} & \multirow{2}{*}{$\begin{array}{l}\text { Lipid content } \\
\text { (\% WW) }\end{array}$} & \multicolumn{3}{|c|}{ Lipid classes (\% of total lipids) } \\
\hline & & & TAG & Sterol & PL \\
\hline \multicolumn{6}{|l|}{ Initial condition } \\
\hline Day 0 & $205 \pm 53$ & $3.2 \pm 0.4$ & $28.6 \pm 3.1$ & $0.5 \pm 0.1$ & $61.7 \pm 1.5$ \\
\hline \multicolumn{6}{|l|}{ Phytoplankton } \\
\hline Diatoms - High & $301 \pm 61$ & $4.4 \pm 0.9$ & $31.6 \pm 1.4$ & $1.6 \pm 0.9$ & $61.2 \pm 0.8$ \\
\hline \multicolumn{6}{|l|}{ Cryptomonads } \\
\hline Low & $271 \pm 18$ & $6.0 \pm 0.1$ & $46.8 \pm 5.1$ & $1.4 \pm 0.6$ & $45.1 \pm 6.3$ \\
\hline Medium & $220 \pm 57$ & $5.5 \pm 0.5$ & $44.7 \pm 9.6$ & $1.0 \pm 0.2$ & $49.4 \pm 9.6$ \\
\hline High & $265 \pm 96$ & $5.2 \pm 0.4$ & $41.5 \pm 5.9$ & $1.0 \pm 0.1$ & $53.7 \pm 6.3$ \\
\hline Dinoflagellates - High & $291 \pm 93$ & $5.4 \pm 0.6$ & $35.6 \pm 3.5$ & $1.5 \pm 0.5$ & $57.0 \pm 4.7$ \\
\hline Thraustochytrids - High & $234 \pm 39$ & $4.9 \pm 0.9$ & $34.4 \pm 3.0$ & $1.0 \pm 0.3$ & $57.5 \pm 3.3$ \\
\hline \multicolumn{6}{|l|}{ Zooplankton } \\
\hline Rotifers - Thraustochytrids & $225 \pm 30$ & $3.6 \pm 1.8$ & $39.7 \pm 8.8$ & $1.2 \pm 0.2$ & $48.2 \pm 8.6$ \\
\hline Artemia - Thraustochytrids & $271 \pm 96$ & $4.0 \pm 0.8$ & $230.2 \pm 2.9$ & $0.7 \pm 0.2$ & $61.7 \pm 2.5$ \\
\hline
\end{tabular}


Table 4. Euphausia superba fed phytoplankton and zooplankton. Wet weight of whole body and digestive gland, lipid content and lipid class composition of DG in relation to source and concentration of food. Data are mean $\pm \mathrm{SD}(\mathrm{N}=3$ ). TAG = triacylglycerol; $\mathrm{PL}=$ polar lipids

\begin{tabular}{|c|c|c|c|c|c|c|}
\hline \multirow[t]{2}{*}{ Diet } & \multicolumn{2}{|c|}{ Wet weight (mg) } & \multirow{2}{*}{$\begin{array}{l}\text { Lipid content } \\
\text { (\% WW DG) }\end{array}$} & \multicolumn{3}{|c|}{ Lipid classes (\% of total lipids) } \\
\hline & Whole body & DG & & TAG & Sterol & PL \\
\hline \multicolumn{7}{|l|}{ Initial condition } \\
\hline Day 0 & $231 \pm 57$ & $2.9 \pm 1.1$ & $5.1 \pm 1.1$ & $29.6 \pm 0.4$ & $1.2 \pm 0.2$ & $37.5 \pm 3.6$ \\
\hline \multicolumn{7}{|l|}{ Phytoplankton } \\
\hline \multicolumn{7}{|l|}{ Diatoms } \\
\hline Low & $312 \pm 129$ & $9.7 \pm 4.5$ & $7.0 \pm 0.8$ & $31.8 \pm 9.1$ & $0.9 \pm 0.1$ & $64.9 \pm 7.0$ \\
\hline Medium & $266 \pm 88$ & $9.3 \pm 3.4$ & $5.7 \pm 0.8$ & $39.1 \pm 5.5$ & $0.6 \pm 0.2$ & $58.0 \pm 3.7$ \\
\hline High & $309 \pm 121$ & $9.2 \pm 3.5$ & $3.5 \pm 1.4$ & $7.7 \pm 13.3$ & $10.3 \pm 8.6$ & $79.9 \pm 8.8$ \\
\hline \multicolumn{7}{|l|}{ Cryptomonads } \\
\hline Low & $279 \pm 91$ & $8.4 \pm 3.3$ & $14.7 \pm 2.0$ & $77.0 \pm 4.2$ & $0.3 \pm 0.1$ & $21.5 \pm 3.4$ \\
\hline Medium & $220 \pm 74$ & $8.1 \pm 3.4$ & $13.2 \pm 4.6$ & $75.7 \pm 7.6$ & $0.6 \pm 0.5$ & $22.3 \pm 7.2$ \\
\hline High & $251 \pm 69$ & $6.9 \pm 3.6$ & $11.1 \pm 3.3$ & $76.5 \pm 3.0$ & $0.8 \pm 0.6$ & $21.3 \pm 3.1$ \\
\hline \multicolumn{7}{|l|}{ Dinoflagellates } \\
\hline Low & $250 \pm 164$ & $4.3 \pm 3.5$ & $7.9 \pm 1.8$ & $28.0 \pm 5.7$ & $1.1 \pm 0.1$ & $68.9 \pm 3.4$ \\
\hline High & $271 \pm 59$ & $8.4 \pm 3.6$ & $5.0 \pm 0.9$ & $25.7 \pm 28.5$ & $8.4 \pm 12.5$ & $63.5 \pm 19.9$ \\
\hline \multicolumn{7}{|l|}{ Thraustochytrids } \\
\hline Low & $242 \pm 31$ & $6.8 \pm 3.2$ & $3.7 \pm 0.9$ & $32.8 \pm 9.4$ & $1.1 \pm 0.4$ & $62.3 \pm 6.5$ \\
\hline Medium & $271 \pm 42$ & $5.8 \pm 2.3$ & $4.8 \pm 1.3$ & $30.0 \pm 10.5$ & $0.9 \pm 0.4$ & $63.4 \pm 5.7$ \\
\hline High & $253 \pm 61$ & $6.2 \pm 3.1$ & $5.0 \pm 0.9$ & $28.6 \pm 17.5$ & $0.8 \pm 0.3$ & $67.0 \pm 12.0$ \\
\hline Saturating & $247 \pm 45$ & $5.8 \pm 2.2$ & $5.6 \pm 1.1$ & $36.0 \pm 19.4$ & $0.6 \pm 0.2$ & $57.9 \pm 12.1$ \\
\hline \multicolumn{7}{|l|}{ Zooplankton } \\
\hline \multicolumn{7}{|l|}{ Rotifers } \\
\hline Diatoms & $327 \pm 109$ & $4.9 \pm 1.7$ & $6.0 \pm 1.3$ & $30.2 \pm 3.2$ & $0.9 \pm 0.5$ & $65.2 \pm 1.4$ \\
\hline Cryptomonads & $264 \pm 71$ & $5.7 \pm 1.4$ & $5.0 \pm 1.1$ & $28.6 \pm 7.0$ & $0.8 \pm 0.3$ & $67.3 \pm 11.0$ \\
\hline Thraustochytrids & $240 \pm 55$ & $4.3 \pm 1.8$ & $7.3 \pm 2.9$ & $41.5 \pm 21.9$ & $0.6 \pm 0.5$ & $53.7 \pm 17.8$ \\
\hline \multicolumn{7}{|l|}{ Artemia } \\
\hline Diatoms & $254 \pm 111$ & $4.9 \pm 2.4$ & $3.7 \pm 0.4$ & $32.3 \pm 14.2$ & $1.1 \pm 0.3$ & $60.5 \pm 13.4$ \\
\hline Cryptomonads & $269 \pm 84$ & $5.6 \pm 2.2$ & $5.5 \pm 0.6$ & $35.8 \pm 3.8$ & $1.3 \pm 1.0$ & $57.1 \pm 5.6$ \\
\hline Thraustochytrids & $251 \pm 69$ & $5.5 \pm 2.5$ & $7.5 \pm 2.9$ & $32.8 \pm 3.0$ & $0.3 \pm 0.5$ & $59.1 \pm 16.8$ \\
\hline
\end{tabular}

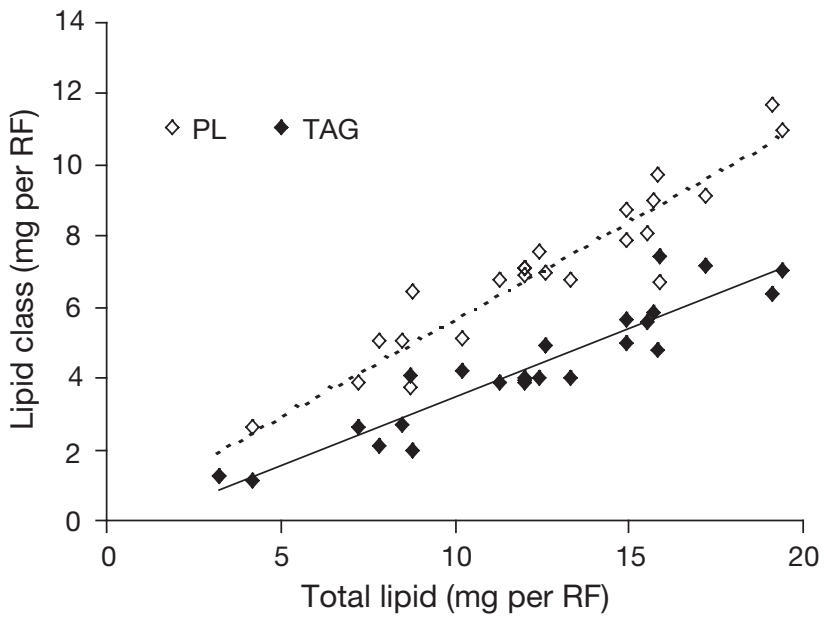

Fig. 1. Euphausia superba fed phytoplankton and zooplankton. Changes in the lipid class composition of the remaining fraction (RF, whole animal minus digestive gland) in relation to total lipid content. TAG (tryacylglycerol, continuous line): $\mathrm{N}=24, \mathrm{R}^{2}=0.87, \mathrm{p}<0.001, y=0.39 x-0.40$. PL (polar lipids dashed line): $\mathrm{N}=24, \mathrm{R}^{2}=0.90, \mathrm{p}<0.001, \mathrm{y}=0.55 \mathrm{x}+0.11$ trends were associated with body size rather than lipid storage. This was also true for whole krill $(\mathrm{N}=27, \mathrm{p}=$ 0.06), as RF contributed to a major fraction of total lipid content (from 77 to $94 \%$ ), i.e. DG lipid class composition varied with both total lipid and food source (Fig. 2), but this was masked when whole krill were considered.

Below a value of $0.5 \mathrm{mg}$ total lipid per DG, changes in DG lipid content were associated with accumulation of both TAG and PL (Fig. 3). Above this value, PL reached a mean maximum of $0.31 \mathrm{mg}$ per DG for krill fed on diatoms, cryptomonads or dinoflagellates, with further accumulation entirely due to TAG (Fig. 3D). In krill fed thraustochytrids, relatively low amounts of TAG were recorded compared to other phytoplankton diets, and PL accumulation was maintained over the $0.5 \mathrm{mg}$ total lipid threshold (dashed lines in Fig. 3C).

\section{Fatty acid profiles}

FA concentration varied from 450 to $760 \mathrm{mg} \mathrm{g}^{-1}$ lipids in whole krill. These variations were not related 


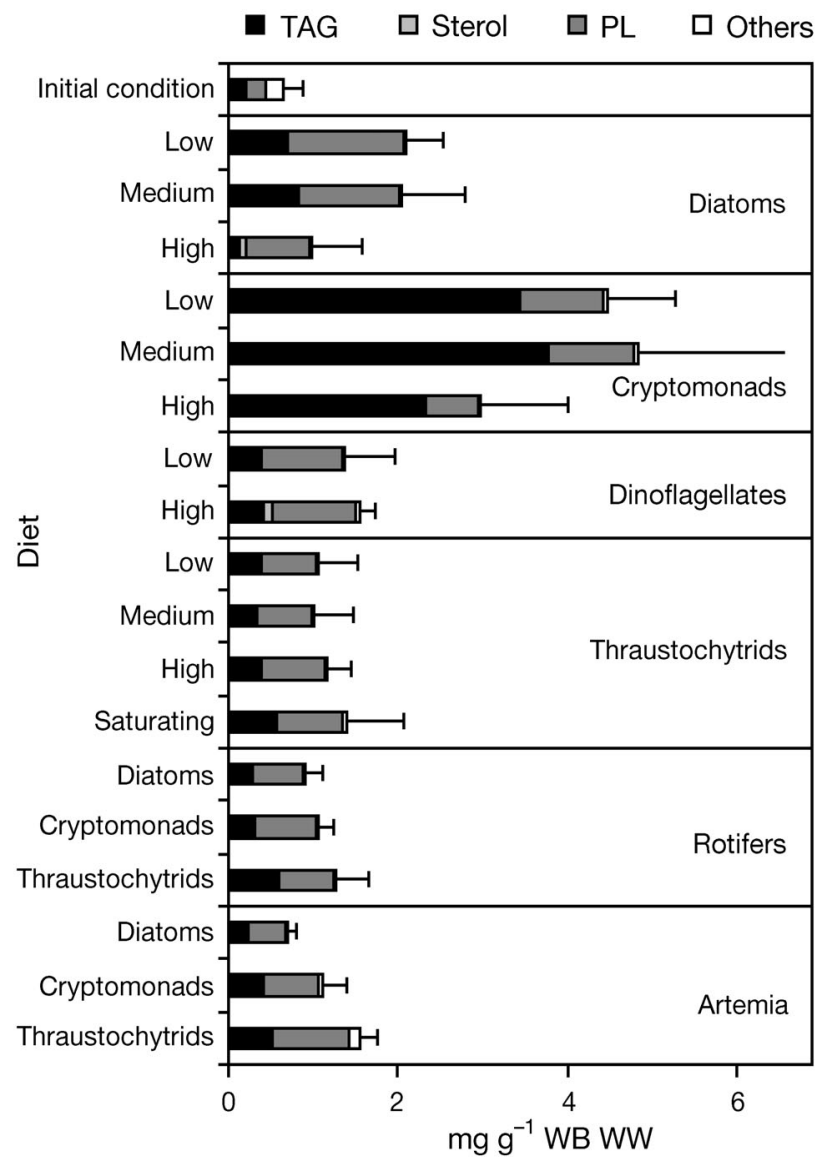

Fig. 2. Euphausia superba fed phytoplankton and zooplankton. Lipid class composition of the digestive gland (as $\mathrm{mg} \mathrm{g}^{-1}$ of whole body WW $)$ in relation to diet. Error bars $=\mathrm{SD}(\mathrm{N}=3)$

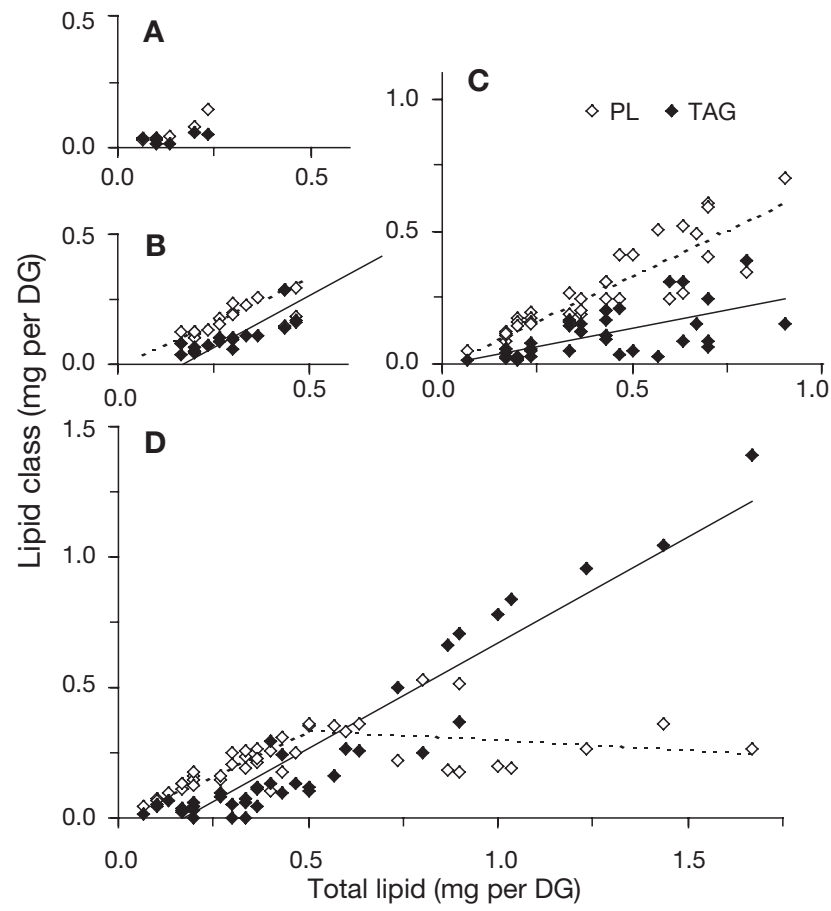

Fig. 3. Euphausia superba. Changes in the lipid class composition of the digestive gland (DG) in relation to lipid content (as mg per DG). (A) Initial condition, (B) krill fed zooplankton, (C) krill fed thraustochytrids, (D) krill fed other phytoplankton (diatoms, cryptomonads and dinoflagellates). TAG (triacylglycerol): $\mathrm{N}=61, \mathrm{R}^{2}=0.90, \mathrm{p}<0.001, y=0.81 \mathrm{x}$ - 0.14, except krill fed thraustochytrids: $\mathrm{N}=36, \mathrm{R}^{2}=0.39$, $\mathrm{p}<0.001, y=0.27 x$. PL (polar lipids): $\mathrm{N}=86, \mathrm{R}^{2}=0.81$, $\mathrm{p}<0.001, y=0.68 x-0.01$ for $x \leq 0.51$ or krill fed thraustochytrids; $\mathrm{N}=15, \mathrm{R}^{2}=0.06, \mathrm{p}=0.40, y=-0.08 x+0.38$ for $x \geq 0.51$ except krill fed thraustochytrids

Table 5. Euphausia superba fed phytoplankton and zooplankton. Fatty acid composition (percent of total FA) of whole krill in

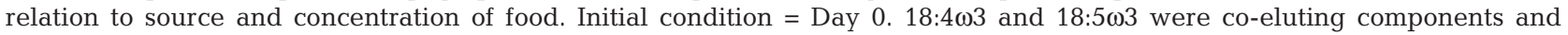
were not quantified separately in DG of dinoflagellate-fed krill. Data are mean $\pm \mathrm{SD}(\mathrm{N}=3)$. ANOVA comparing diets: ${ }^{*} \mathrm{p} \leq 0.05$, ${ }^{* *} \mathrm{p} \leq 0.01,{ }^{* * *} \mathrm{p} \leq 0.001$

\begin{tabular}{|c|c|c|c|c|c|c|c|c|c|}
\hline Fatty acid & $\begin{array}{c}\text { Initial } \\
\text { condition }\end{array}$ & $\begin{array}{l}\text { Diatoms } \\
\text { High }\end{array}$ & \multicolumn{3}{|c|}{ Cryptomonads } & $\begin{array}{l}\text { Dino } \\
\text { High }\end{array}$ & $\begin{array}{c}\text { Thrausto } \\
\text { High }\end{array}$ & $\begin{array}{l}\text { Rotifers } \\
\text { Thrausto }\end{array}$ & $\begin{array}{l}\text { Artemia } \\
\text { Thrausto }\end{array}$ \\
\hline $14: 0$ & $10.3 \pm 1.2$ & $10.9 \pm 1.6$ & $10.8 \pm 0.5$ & $10.2 \pm 1.0$ & $10.1 \pm 1.3$ & $11.5 \pm 0.7$ & $12.1 \pm 0.8$ & $10.6 \pm 1.5$ & $10.2 \pm 0.4$ \\
\hline $16: 1 \omega 7 \mathrm{C}^{*}$ & $9.6 \pm 1.2$ & $10.3 \pm 0.2$ & $9.8 \pm 0.1$ & $8.6 \pm 0.5$ & $8.4 \pm 0.7$ & $8.4 \pm 0.5$ & $10.0 \pm 0.1$ & $9.7 \pm 0.5$ & $9.8 \pm 1.0$ \\
\hline 16:0 & $19.9 \pm 0.9$ & $21.9 \pm 0.6$ & $21.3 \pm 0.2$ & $21.4 \pm 0.4$ & $21.1 \pm 2.7$ & $22.0 \pm 0.3$ & $20.7 \pm 0.3$ & $20.0 \pm 1.4$ & $20.3 \pm 0.4$ \\
\hline $18: 3 \omega 6$ & $0.3 \pm 0.0$ & $0.3 \pm 0.0$ & $0.2 \pm 0.0$ & $0.2 \pm 0.0$ & $0.3 \pm 0.0$ & $0.3 \pm 0.0$ & $0.3 \pm 0.0$ & $0.7 \pm 0.7$ & $0.3 \pm 0.1$ \\
\hline $18: 4 \omega 3^{* *}$ & $2.1 \pm 0.5$ & $1.5 \pm 0.1$ & $3.4 \pm 0.3$ & $3.8 \pm 0.9$ & $3.6 \pm 1.1$ & $4.0 \pm 1.7$ & $2.0 \pm 0.3$ & $1.6 \pm 1.5$ & $1.9 \pm 0.2$ \\
\hline $18: 2 \omega 6^{*}$ & $5.2 \pm 1.0$ & $4.3 \pm 0.7$ & $3.6 \pm 0.1$ & $3.7 \pm 0.5$ & $3.5 \pm 0.3$ & $4.2 \pm 0.8$ & $4.2 \pm 0.2$ & $4.9 \pm 0.7$ & $5.3 \pm 0.6$ \\
\hline $18: 1 \omega 9 \mathrm{C}^{* * *}$ & $11.4 \pm 1.8$ & $10.2 \pm 0.7$ & $17.3 \pm 1.3$ & $16.3 \pm 2.7$ & $15.2 \pm 2.3$ & $11.5 \pm 0.5$ & $9.8 \pm 1.5$ & $10.7 \pm 1.8$ & $10.8 \pm 0.6$ \\
\hline $18: 1 \omega 7 \mathrm{C}^{* * *}$ & $8.4 \pm 0.4$ & $7.5 \pm 0.2$ & $6.8 \pm 0.1$ & $6.6 \pm 0.7$ & $6.8 \pm 0.2$ & $7.0 \pm 0.1$ & $7.5 \pm 0.3$ & $7.5 \pm 0.3$ & $8.2 \pm 0.3$ \\
\hline $18: 0$ & $0.8 \pm 0.5$ & $1.4 \pm 0.1$ & $1.2 \pm 0.1$ & $1.4 \pm 0.3$ & $1.2 \pm 0.2$ & $1.4 \pm 0.3$ & $0.9 \pm 0.1$ & $1.3 \pm 0.3$ & $1.2 \pm 0.0$ \\
\hline $20: 5 \omega 3(\mathrm{EPA})^{* * *}$ & $15.3 \pm 1.0$ & $14.3 \pm 0.9$ & $11.0 \pm 0.6$ & $11.8 \pm 1.0$ & $12.2 \pm 1.0$ & $12.3 \pm 0.1$ & $13.6 \pm 0.4$ & $14.9 \pm 0.8$ & $15.2 \pm 0.5$ \\
\hline $22: 5 \omega 6^{* * *}$ & $0.0 \pm 0.0$ & $0.0 \pm 0.0$ & $0.0 \pm 0.0$ & $0.1 \pm 0.3$ & $0.0 \pm 0.0$ & $0.0 \pm 0.0$ & $0.8 \pm 0.5$ & $0.2 \pm 0.0$ & $0.0 \pm 0.0$ \\
\hline $22: 6 \omega 3(\mathrm{DHA}) * *$ & $8.5 \pm 0.8$ & $7.2 \pm 0.5$ & $6.0 \pm 0.2$ & $6.7 \pm 1.1$ & $6.7 \pm 0.8$ & $8.4 \pm 0.7$ & $10.2 \pm 2.1$ & $9.0 \pm 1.8$ & $8.7 \pm 0.4$ \\
\hline Other & 8.2 & 10.0 & 8.5 & 9.2 & 10.9 & 9.1 & 8.0 & 9.1 & 8.1 \\
\hline $16: 1 \omega 7 \mathrm{c} / 16: 0$ & 0.5 & 0.5 & 0.5 & 0.4 & 0.4 & 0.4 & 0.5 & 0.5 & 0.5 \\
\hline $18: 1 \omega 7 \mathrm{c} / 18: 1 \omega 9 \mathrm{c}$ & 0.7 & 0.7 & 0.4 & 0.4 & 0.4 & 0.6 & 0.8 & 0.7 & 0.8 \\
\hline EPA/DHA & 1.8 & 2.0 & 1.8 & 1.8 & 1.8 & 1.5 & 1.3 & 1.7 & 1.7 \\
\hline Total $\omega 7 \mathrm{c}$ & 18.6 & 18.5 & 17.2 & 15.8 & 15.8 & 16.1 & 18.0 & 17.8 & 18.6 \\
\hline Total $\omega 3$ & 27.2 & 24.2 & 21.4 & 23.4 & 23.3 & 25.8 & 27.0 & 26.3 & 27.1 \\
\hline
\end{tabular}




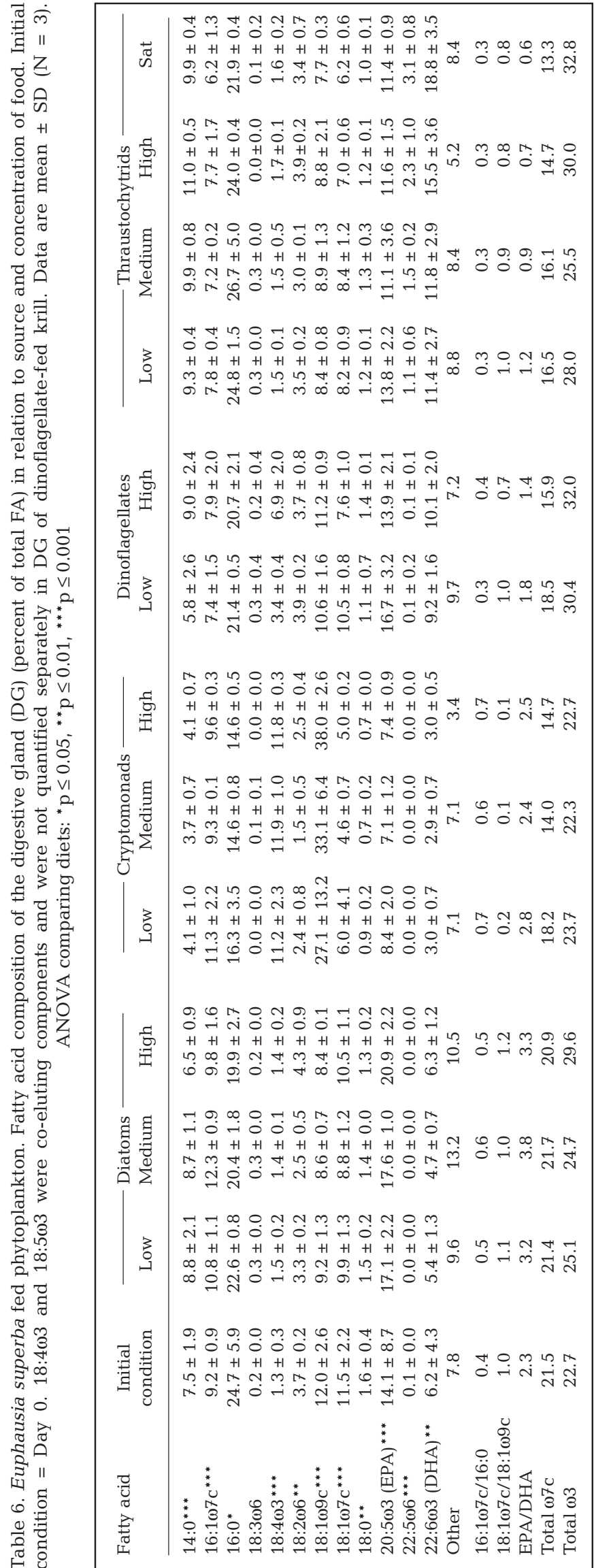

to diets $(\mathrm{N}=27, \mathrm{p}=0.32)$. Differences in FA profiles (as percent of total FA) were observed in whole krill in relation to diet (Table 5). These differences, however, remained within the range of a few percent $(7.5 \%$ in $18: 1 \omega 9,4.3 \%$ in $\mathrm{EPA}, 4.2 \%$ in DHA, $<3 \%$ in other $\mathrm{FA}$ ) and were not as significant as those observed in DG (Tables $5 \& 6$ ). This is because the FA composition of RF, which contributed to a major fraction of FA in whole krill, showed only small changes. These were associated mainly with higher proportions of 18:1 19 in cryptomonad-fed krill (14.1 to $15.8 \%$ of total FA) than in RF of other krill (9.8 to $11.4 \%$ ), with no trend observed in relation to food level. Thus, changes observed in whole krill were mainly caused by a great variability in the FA composition of DG.

Phytoplankton diets induced markedly different changes in the FA composition of DG (Table 6, Fig. 4). On an absolute basis (mg per WW), FA followed the patterns observed for total lipids, i.e. they were accumulated during feeding experiments, but their accumulation at the high concentration of diatoms and cryptomonads was approximately half that observed at lower food concentrations. The total FA concentration at medium and high food concentrations $(710 \mathrm{mg}$ $\mathrm{g}^{-1}$ lipid), however, was greater than at the low food concentration or in DG on Day 0 (430 $\mathrm{mg} \mathrm{g}^{-1}$ lipid). On a relative basis (as \% total FA), feeding on diatoms essentially resulted in a concentration-dependent increase in EPA from 14.1 to 17.1 of total FA at the low food concentration to $17.6 \%$ at the medium and up to $20.9 \%$ at the high. Compared to Day 0, 16:167, the other major FA of diatoms, did not change significantly in the DG, whereas it decreased with other phytoplankton diets. Cryptomonad-fed krill showed striking increases in the contribution of 18:1 $\omega 9$ (from $12.0 \%$ in controls, to 27.1 to $38.0 \%$ ) and $18: 4 \omega 3$ (from 1.3 to an average of $11.6 \%$ ). Proportions of those FA were correlated to the concentration of food. A high level of dinoflagellates yielded increased amounts of C18 polyunsaturated fatty acids (PUFA) (from 1.3 to $6.9 \%$ ) and DHA (from 6.2 to $10.1 \%$ ). C18 PUFA were

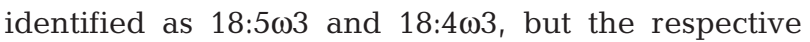
amounts of these 2 FA were not quantified separately. Maximum proportions of DHA were recorded in thraustochytrid-fed krill (from $11.4 \%$ of total FA at low level to $18.8 \%$ at saturating level). An increased amount of 16:0 was also observed, but this trend was

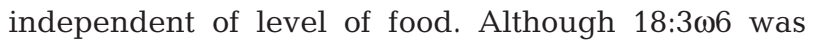
abundant in cryptomonads (17.6\% of total FA) and $22: 5 \omega 6$ was abundant in thraustochytrids (12.9\%), their quantities remained very low in krill fed on these diets. These results suggest that these 2 FA were not accumulated in krill.

Although the FA concentration increased slightly in DG when krill were fed on zooplankton diets (from 430 


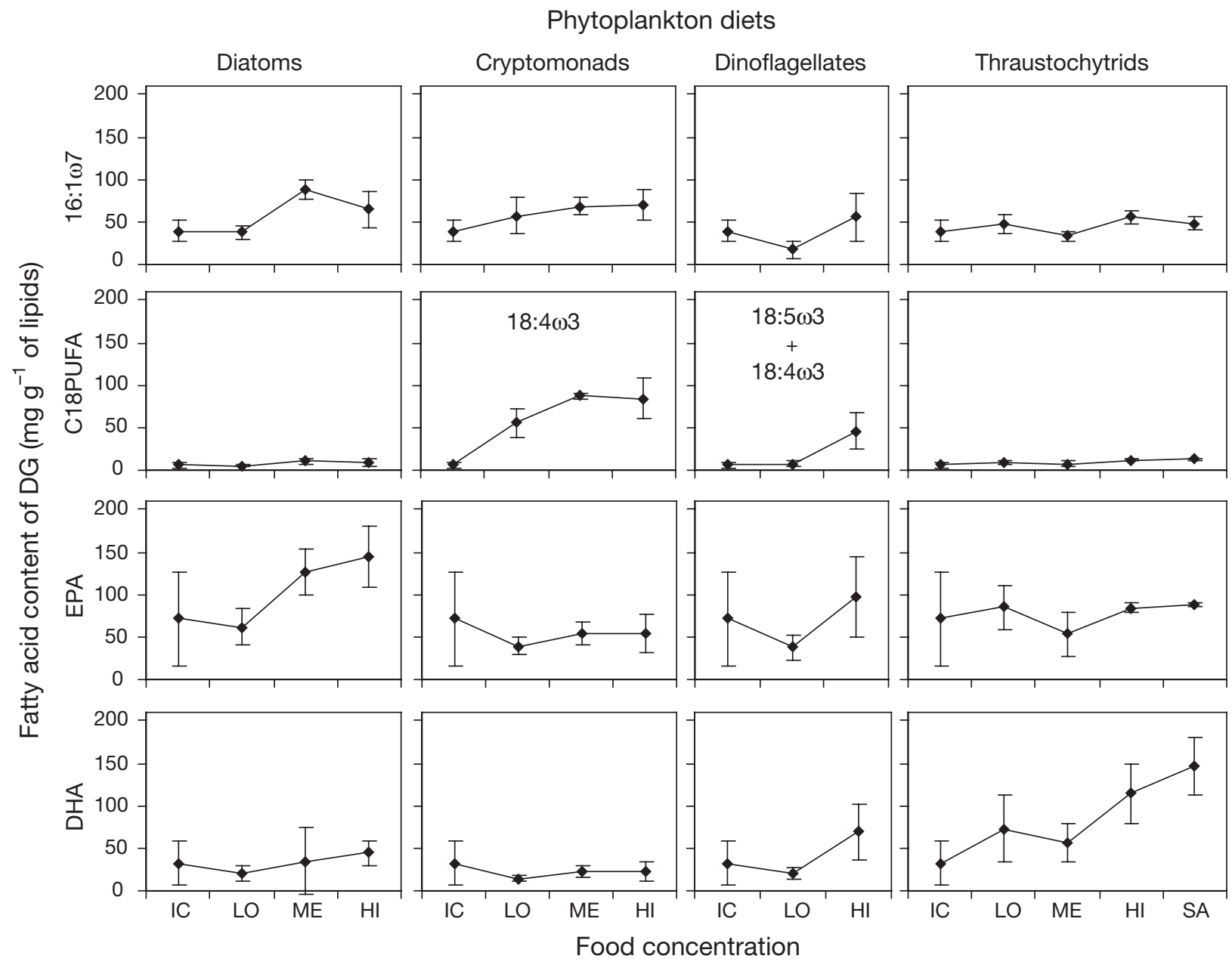

Fig. 4. Euphausia superba fed phytoplankton. Changes in major fatty acid content of the digestive gland in relation to diet and food level $(\mathrm{LO}=$ low, $\mathrm{ME}=$ medium, $\mathrm{HI}=$ high, $\mathrm{SA}=$ saturating, $\mathrm{IC}=$ initial condition). Error bars $=\mathrm{SD}(\mathrm{N}=3)$

to $520 \mathrm{mg} \mathrm{g}^{-1}$ lipid), FA profiles did not differ significantly from those observed on Day 0 (Table 7, Fig. 5). In rotifer-fed krill, the proportions of DHA and 18:1 19 in DG increased respectively when prey were enriched on thraustochytrids and cryptomonads $(\mathrm{N}=3$, $p=0.06$ and $p=0.045$ respectively), but these differences were much smaller than those observed among DG from krill fed with the phytoplankton diets.

\section{Fatty acid ratios}

Fatty acid ratios, $16: 1 \omega 7 \mathrm{c} / 16: 0, \quad 18: 1 \omega 7 \mathrm{c} / 18: 1 \omega 9 \mathrm{c}$ and EPA/DHA, showed significant differences among treatments in whole krill $(\mathrm{p}=0.01, \mathrm{p}=0.001, \mathrm{p}=0.01$ respectively) and in their DG ( $p<0.001$ in all cases). These differences were not as marked in whole krill as in DG (Tables 5 to 7 ). In DG, 16:1 $107 \mathrm{c} / 16: 0$ was relatively high when krill were fed on cryptomonads (0.6 to 0.7 ) and diatoms (0.5 to 0.6$)$ compared to other diets (0.3 to 0.4$)$. In whole krill, variations were small (0.4 to 0.5$)$ and independent of $16: 1 \omega 7 \mathrm{C}$ concentrations in the diets. Values of $18: 1 \omega 7 \mathrm{c} / 18: 1 \omega 9 \mathrm{c}$ in DG were lowest in cryptomonad-fed krill (0.1 to 0.2 ) and highest in diatom-fed krill (1.0 to 1.2). The values observed in the DG for other diets (zooplankton, dinoflagellates and thraustochytrids) were similar (0.6 to 1.0). In whole krill, $18: 1 \omega 7 \mathrm{c} / 18: 1 \omega 9 \mathrm{c}$ varied over a much smaller range, from 0.4 (cryptomonad-fed krill) to 0.8 (krill fed other diets). In DG, EPA/DHA was maximum in diatom-fed krill (3.2 to 3.8) and was also higher in krill fed on cryptomonads (2.5 to 2.8 ) than on the dinoflagellate DHA-rich diet (1.4 to 1.8$)$. Low ratios $(\leq 1.2)$ were observed in thraustochytrid-fed krill, where EPA originated from the retroconversion of DHA. DG showed intermediate EPA/DHA ratios (2.0 to 2.4) when krill were fed on zooplankton, although rotifers enriched on diatoms induced a relatively high value (3.4). EPA/DHA varied within a small range when whole krill were considered, from 1.3 (thraustochytrids) to 2.0 (diatoms). 
Table 7. Euphausia superba fed zooplankton. Fatty acid composition (percent of total FA) of krill digestive gland in relation to zooplankton diet and primary food source used during enrichment (Crypto $=$ cryptomonads; Thrausto $=$ thraustochytrids). Initial condition $=$ Day 0 . Data are mean $\pm \mathrm{SD}(\mathrm{N}=3)$. ANOVA comparing diets: ${ }^{*} \mathrm{p} \leq 0.05$

\begin{tabular}{|c|c|c|c|c|c|c|c|}
\hline Fatty acid & $\begin{array}{c}\text { Initial } \\
\text { condition }\end{array}$ & Diatoms & $\begin{array}{l}\text { Rotifers } \\
\text { Crypto }\end{array}$ & Thrausto & Diatoms & $\begin{array}{l}\text { Artemia } \\
\text { Crypto }\end{array}$ & Thrausto \\
\hline $14: 0$ & $7.5 \pm 1.9$ & $10.3 \pm 0.7$ & $9.7 \pm 1.0$ & $6.7 \pm 1.0$ & $8.2 \pm 1.8$ & $9.6 \pm 1.9$ & $7.2 \pm 1.8$ \\
\hline $16: 1 \omega 7 \mathrm{c}$ & $9.2 \pm 0.9$ & $8.6 \pm 0.5$ & $8.8 \pm 0.9$ & $8.1 \pm 1.0$ & $8.3 \pm 2.2$ & $8.1 \pm 1.5$ & $7.3 \pm 1.1$ \\
\hline $16: 0$ & $24.7 \pm 5.9$ & $23.0 \pm 1.7$ & $23.5 \pm 2.6$ & $20.7 \pm 1.0$ & $20.3 \pm 0.4$ & $20.8 \pm 1.1$ & $19.3 \pm 0.2$ \\
\hline $18: 3 \omega 6$ & $0.2 \pm 0.0$ & $0.1 \pm 0.2$ & $0.1 \pm 0.1$ & $0.3 \pm 0.1$ & $0.1 \pm 0.1$ & $0.2 \pm 0.2$ & $0.3 \pm 0.0$ \\
\hline $18: 4 \omega 3^{*}$ & $1.3 \pm 0.3$ & $1.5 \pm 0.2$ & $2.0 \pm 0.3$ & $1.7 \pm 0.1$ & $1.8 \pm 0.1$ & $1.7 \pm 0.3$ & $1.5 \pm 0.2$ \\
\hline $18: 2 \omega 6$ & $3.7 \pm 0.2$ & $4.6 \pm 0.8$ & $4.6 \pm 1.0$ & $5.0 \pm 0.9$ & $5.1 \pm 0.9$ & $4.4 \pm 0.7$ & $4.6 \pm 0.7$ \\
\hline $18: 1 \omega 9 c$ & $12.0 \pm 2.6$ & $12.1 \pm 0.5$ & $14.0 \pm 1.2$ & $11.1 \pm 1.4$ & $12.3 \pm 0.4$ & $13.4 \pm 1.0$ & $12.6 \pm 0.3$ \\
\hline $18: 1 \omega 7 \mathrm{c}$ & $11.5 \pm 2.2$ & $9.4 \pm 0.9$ & $8.9 \pm 1.2$ & $9.3 \pm 0.6$ & $10.4 \pm 1.1$ & $9.8 \pm 0.6$ & $9.8 \pm 1.4$ \\
\hline 18:0 & $1.6 \pm 0.4$ & $1.7 \pm 0.2$ & $2.1 \pm 0.5$ & $1.6 \pm 0.0$ & $1.8 \pm 0.2$ & $1.7 \pm 0.3$ & $1.8 \pm 0.3$ \\
\hline 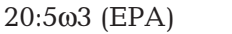 & $14.1 \pm 8.7$ & $17.5 \pm 0.6$ & $14.5 \pm 2.6$ & $16.7 \pm 1.4$ & $16.4 \pm 3.1$ & $16.2 \pm 1.1$ & $17.0 \pm 0.8$ \\
\hline $22: 5 \omega 6^{*}$ & $0.1 \pm 0.0$ & $0.0 \pm 0.0$ & $0.0 \pm 0.0$ & $0.3 \pm 0.1$ & $0.0 \pm 0.1$ & $0.0 \pm 0.0$ & $0.2 \pm 0.1$ \\
\hline 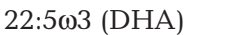 & $6.2 \pm 4.3$ & $5.2 \pm 4.4$ & $6.4 \pm 1.4$ & $8.6 \pm 0.4$ & $7.6 \pm 2.0$ & $6.7 \pm 0.2$ & $8.2 \pm 0.2$ \\
\hline Other & 7.8 & 5.9 & 5.4 & 10.0 & 7.7 & 7.3 & 10.2 \\
\hline $16: 1 \omega 7 \mathrm{c} / 16: 0$ & 0.4 & 0.4 & 0.4 & 0.4 & 0.4 & 0.4 & 0.4 \\
\hline $18: 1 \omega 7 \mathrm{c} / 18: 1 \omega 9 \mathrm{c}$ & 1.0 & 0.8 & 0.6 & 0.8 & 0.8 & 0.7 & 0.8 \\
\hline EPA/DHA & 2.3 & 3.4 & 2.3 & 2.0 & 2.2 & 2.4 & 2.1 \\
\hline Total $\omega 7 \mathrm{C}$ & 21.5 & 18.2 & 17.9 & 17.7 & 18.9 & 18.3 & 17.5 \\
\hline Total $\omega 3$ & 22.7 & 25.1 & 23.8 & 28.4 & 27.1 & 25.6 & 28.0 \\
\hline
\end{tabular}

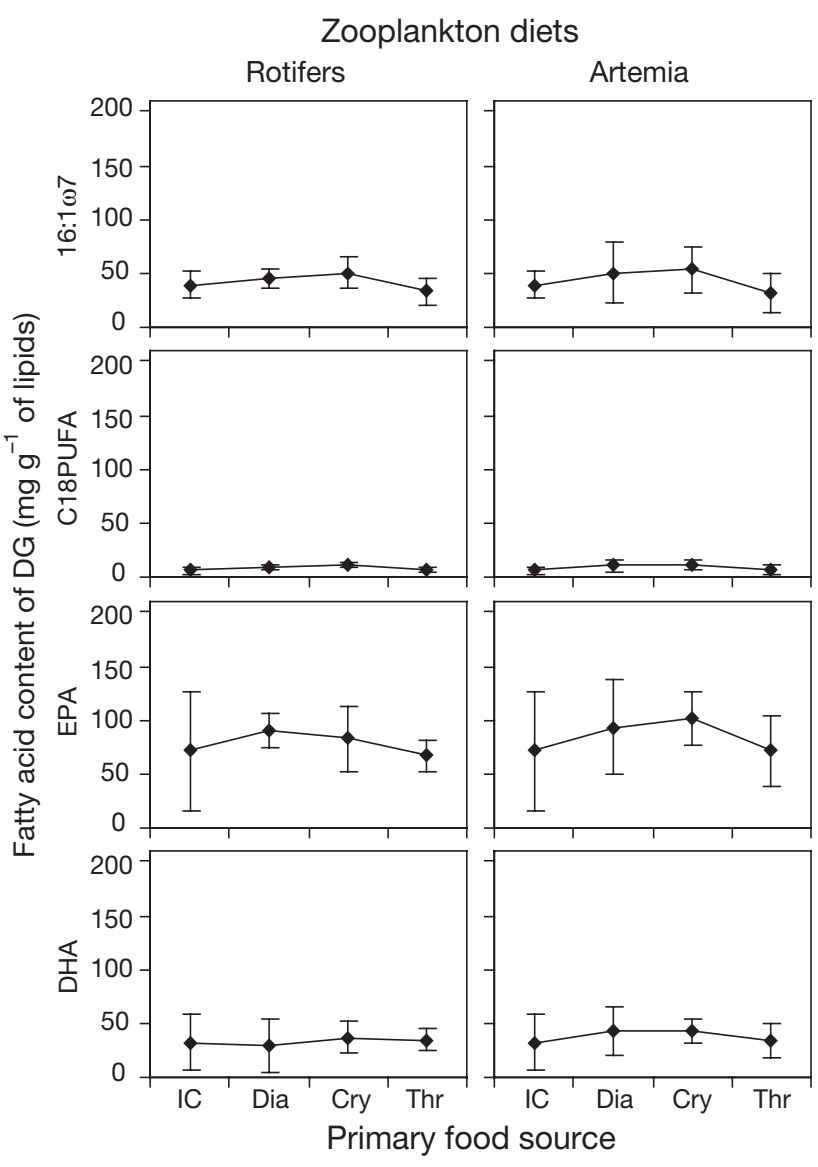

Fig. 5. Euphausia superba fed zooplankton. Changes in major fatty acid content of the digestive gland in relation to zooplankton diet and primary food source used during enrichment $($ Dia $=$ diatoms, Cry $=$ cryptomonads, $\mathrm{Thr}=$ thraustochytrids, IC = initial condition). Error bars $=\mathrm{SD}(\mathrm{N}=3)$

\section{Multivariate analysis of fatty acid profiles in digestive glands}

Four groups of FA were defined using PCA. Correlations between FA proportions were $>0.74$ within each group. These groups included: saturated FA 14:0, 16:0 and 18:0; diatom FA 16:1 $7,18: 1 \omega 7$ and EPA; flagellate FA 18:1 09 and C18 PUFA; and thraustochytrid FA

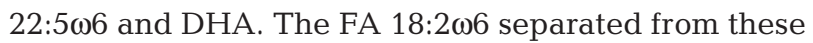
groups with a maximum correlation of 0.71 observed with EPA only.

The first 3 principal components explained $86 \%$ of the variance. Axis 1 was associated with changes in the amount of saturated and diatom FA, and was relatively independent of variations in flagellate and thraustochytrid FA. Axis 2 opposed flagellate FA to thraustochytrid FA. Axes 3 and 4 did not show any trend specific to a particular diet. Axis 5 explained a minor fraction of variance $(3.1 \%)$ but was related solely to

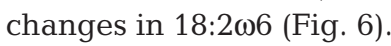

FA profiles of thraustochytrid- and cryptomonad-fed krill were separated from other profiles by PC2. Ordination of profiles on the PC1 - PC2 plane produced no clear discrimination among krill fed on diatoms, dinoflagellates and zooplankton. Therefore, the PC2 PC5 plane was used to compare krill in relation to their diets (Fig. 6). The difference in DG profiles between diatom- and dinoflagellate-fed krill was greatest at the high food concentration, but only small at the low concentration. As a consequence, the distribution of diatom- and dinoflagellate-fed groups was partly overlapping on the PC2 - PC5 plane. Carnivorous krill showed

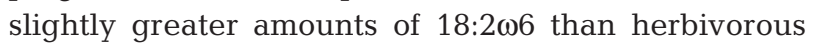


Fig. 6. Euphasia superba. Principal component analysis describing fatty acid profiles of the digestive gland (mg FA ${ }^{-1}$ of lipid). (A) Projections of variables on the PC2 - PC5 plane. (B) Scatter plot of FA profiles in the PC2 - PC5 plane for phytoplankton-fed krill (ordination of zooplankton-fed krill indicated as small dots). (C) Scatter plot of FA profiles in the PC2 - PC5 plane for zooplankton-fed krill (ordination of phytoplanktonfed krill indicated as small dots). Dotted lines represent boundaries of groups, as labelled. The PC5 axis is stretched relative to the PC2 axis, for better visualisation. $\mathrm{EPA}=20: 5 \omega 3 ; \mathrm{DHA}=$ $22: 6 \omega 3$
PC5

(3.1\%)

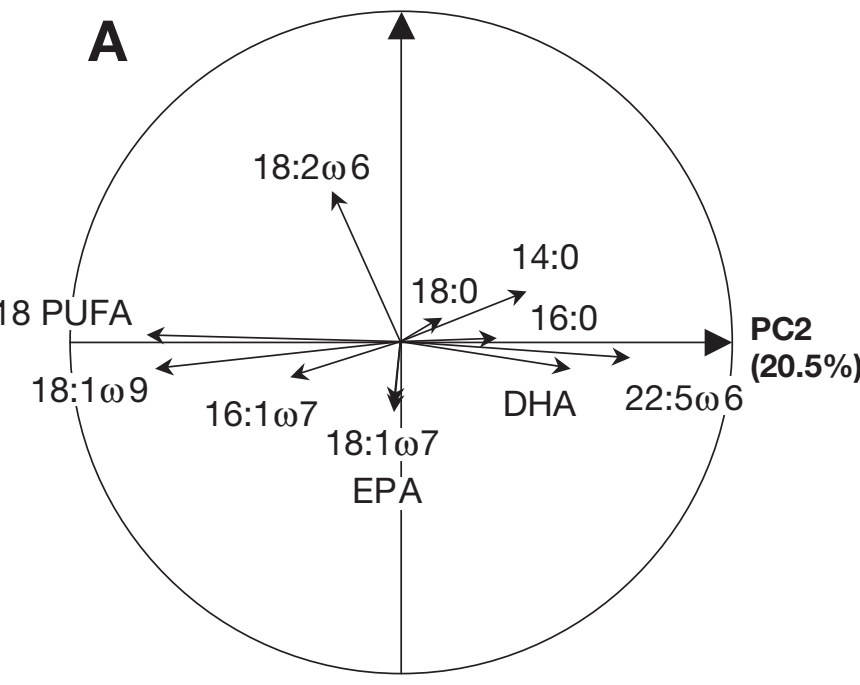

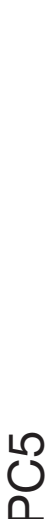

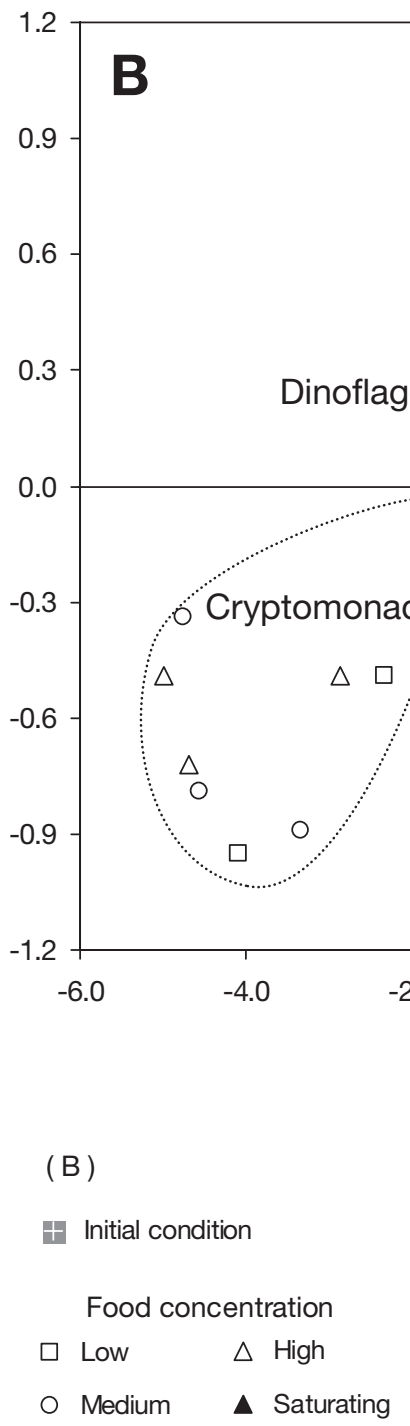

(c)

Rotifers

Artemia spp.

$\mathrm{PC} 2$

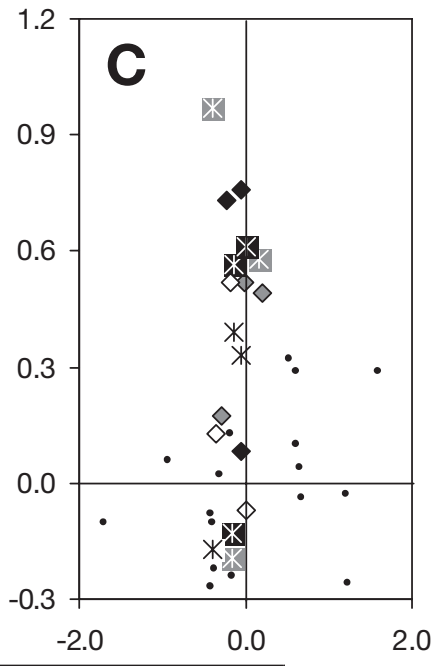

$\triangle \square^{\circ}: \square$

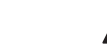

$\Delta$

$\triangle$

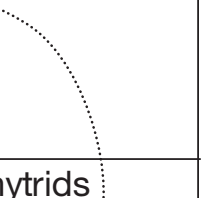

Thraustochytrids

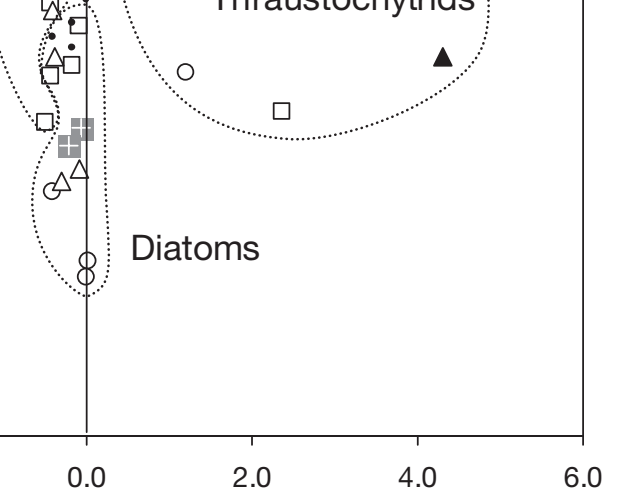

Diatoms

- Cryptomonads

$\diamond$ Thraustochytrids

X Diatoms

W Cryptomonads * Thaustochytrids 
krill and were distinguished on PC5. However, the various zooplankton diets were neither separated according to the species used as prey (rotifers and Artemia) nor to the primary treatment used during enrichment (diatoms, cryptomonads and thraustochytrids).

\section{DISCUSSION}

\section{Influence of diet on lipid composition in Antarctic krill}

Over the last decade, there has been debate about whether changes in lipid composition observed in Euphausia superba can be attributed to diet variations in the wild. In fact, numerous factors, including sex and maturity stages, have been shown to strongly affect the lipid class and FA composition (Clarke 1980, Kolokowska 1991, Pond et al. 1995, Virtue et al. 1996). These effects might predominate over the potential of diet to influence lipid content and composition, and this could explain why only small or no differences have been observed between krill exposed to different diets in the field (Torres et al. 1994, Cripps \& Hill 1998), or fed on different controlled regimes in the laboratory (Stübing \& Hagen 2003, Stübing et al. 2003). In particular, the essential role of long chain PUFA, such as EPA and DHA, in major biological processes causes them to be highly conserved by marine organisms (Sargent \& Henderson 1995) and may interfere with their potential suitability as dietary markers (Hagen et al. 2001, Stübing et al. 2003). However, these conclusions concern lipid composition of whole animals, and studies have suggested that much greater variability in lipid composition might be observed in the DG than in whole animals, both for krill collected in the field or maintained in feeding and starvation conditions (Virtue et al. 1993a,b, 1997, Mayzaud et al. 1998, Alonzo et al. 2003).

The present study demonstrated that controlled diets induce strong changes in lipid class and FA composition of the DG, which acts as a major site for lipid storage and synthesis in Euphausia superba juveniles. Furthermore, by showing that no such changes occurred in the other body regions (remaining fraction), we identified DG as the major repository of much of the lipid trophic signal. In future studies, focusing analyses more effectively on this organ, thereby excluding the background signal, will strongly enhance the utility of lipids as trophic biomarkers.

\section{Fatty acids in DG as dietary markers}

The value of FA as specific trophic markers has been discussed in detail for various zooplankton species, including Euphausia superba (Mayzaud et al. 1976, Sargent et al. 1985, Falk-Petersen et al. 1990, Graeve et al. 1994, Hagen et al. 2001, Alonzo et al. 2003, Dalsgaard et al. 2003, Stübing \& Hagen 2003, Stübing et al. 2003). This approach has been increasingly applied to studies of the feeding ecology of Antarctic krill in the field (Cripps \& Hill 1998, Cripps et al. 1999, Cripps \& Atkinson 2000, Phleger et al. 2002).

Diatoms are an abundant source of 16:1 107 and EPA (Volkman et al. 1989, Dunstan et al. 1994) and a high proportion of these FA is considered to indicate a diatom diet in zooplankton (Sargent et al. 1985, 1987, FalkPetersen et al. 1990, 2000, Graeve et al. 1994) and in Antarctic krill (Cripps et al. 1999). Our results show that this hypothesis requires some caution. Although DG of diatom-fed krill showed high amounts of 16:1 107 (10 to $12 \%$ total FA) and EPA (17 to $20 \%$ ), these FA did not necessarily solely reflect their abundance in the diet. In fact, a similar proportion of 16:1 107 was also observed in DG when krill had fed efficiently on cryptomonads. As only a small amount of 16:1 107 was found in this algal group, accumulation most likely resulted from de novo synthesis in this case. EPA proportions of 11 to $17 \%$ were observed in DG when krill were fed dinoflagellates or thraustochytrids, although this PUFA was absent from both diets. This suggests that an alternate source of EPA in krill could be from the retroconversion of DHA. The EPA/DHA ratio appeared to be a good index of the origin of EPA, with values from 0.6 to 1.8 in the case of retroconversion from DHA and from 2.0 to 3.8 in the case of direct acquisition from food (all other diets).

According to published data, high levels of 18:1 $\omega 9$ in zooplankton, including Antarctic euphausiids, are often associated with a carnivorous diet (e.g. Nelson et al. 2000, Phleger et al. 2002). Although proportions of DG 18:1 19 were slightly greater in zooplankton-fed krill than in most phytoplankton-fed krill (11.1 to 14.0 and 7.7 to $11.2 \%$ respectively), these values were markedly lower than those occurring in this study for krill fed on a cryptomonad diet (up to $38 \%$ of total FA). Cryptomonad-fed krill also showed the greatest proportions of $18: 4 \omega 3(12 \%)$. We propose that high levels of $18: 1 \omega 9$ and $18: 4 \omega 3$ in krill DG may be a marker of intensive feeding on cryptomonads in the field. High amounts of these FA are found in cryptomonads (Volkman et al. 1989). Among other major FA in cryptomonads, 18:3 166 was not detected in DG, and EPA was at the lowest levels observed after $20 \mathrm{~d}$ feeding.

Dinoflagellates are recognised as a major source of 18:5 13 and DHA for zooplankton (Sargent et al. 1985, 1987, Volkman et al. 1989, Falk-Petersen et al. 1990, 2000). In our experiments, dinoflagellate-fed krill showed relatively high proportions of DHA in the DG (10\% of total FA) compared to treatments where this 
PUFA was not present in the diet (3 to $8 \%$ ). However, DHA was most efficiently incorporated in krill fed on thraustochytrids. Members of this cosmopolitan algal group have been isolated in the Antarctic environment and it has therefore been suggested to be an alternative source of this PUFA in the Southern Ocean (e.g. Bahnweg \& Sparrow 1974, Lewis et al. 1999). A high concentration of 18:5 133 (49\% total FA), co-eluting with $18: 4 \omega 3$ ( $3 \%$ total FA), has been observed in the dinoflagellate Polarella glacialis (Thomson et al. 2004). However, 18:5 $\omega 3$ has rarely been reported as a component of Euphausia superba in the field (Phleger et al. 2002), and was not detected in krill fed on Phaeocystis pouchetii (prymnesiophyte), in which it accounted for up to $60 \%$ of total FA (Virtue et al. 1993b). Our results suggest that $18: 5 \omega 3$ was retroconverted to $18: 4 \omega 3$. Its detection in DG might characterise dinoflagellate-fed krill.

\section{Effect of food concentration on DG lipid composition}

Hagen et al. (2001) observed that most major FA accumulate with increasing lipid content in Euphausia superba, which is further interpreted by Stübing et al. (2003) as a potential problem for the use of lipids as trophic markers. We have shown that in the DG, proportions of dietary FA increase with increasing concentration of food, whereas this is not necessarily true for DG lipid content. In fact, maximum proportions of diatom FA (16:1 107 and EPA) and of cryptomonad FA

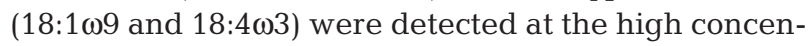
tration of these diets, whereas maximum DG lipid contents were observed at low and medium food concentrations. These inverse relationships between total lipid content and dietary FA contributions might be deemed contradictory. Several mechanisms might explain these results. We observed that feeding rates, therefore dietary lipid intakes (= lipid ingestion $\times 20 \mathrm{~d}$ ), were greatest at the high food concentration. This presumably caused dietary lipids to become dominant in DG over first end-products of de novo biosynthesis, such as 14:0, 16:0 and 16:1 1 7. Furthermore, the small increase in 18:1 $\omega 9$ in the remaining fractions of cryptomonad-fed krill suggests that a fraction of dietary lipids were transferred to other body regions. These hypotheses are supported by the findings that Antarctic krill catabolise a major part of their assimilated lipid, and biosynthesis occurs mainly for saturated FA (Pond et al. 1995, Hagen et al. 2001).

We suggest that the intensity of dietary signatures in Euphausia superba DG (i.e. how dominant dietary markers are in the FA composition) is mainly dependent on feeding rates. These were low in our experiments compared to those observed in situ (Perissi- notto et al. 1997), due to the small incubation volumes employed. This suggests that much stronger dietary signatures might be expected in DG of krill from the wild (EPA $30 \%$ total FA on Day 0 in Virtue et al. 1993a).

\section{Carnivory}

A major aspect of our study was to examine whether FA profiles were indicative of carnivorous feeding and whether these carnivorous signatures might incorporate characteristics of phytoplankton consumed by zooplankton, at the second trophic level. Phytoplankton signatures transferred to krill through zooplankton diets would interfere with the detection of carnivorous behaviour of Euphausia superba in the wild.

Despite its high abundance in zooplankton (up to one third of total FA), 18:1 19 only occurred at slightly higher levels in DG of carnivorous krill (11 to 14\%) than in those of herbivorous krill ( 7 to $11 \%$ ), and this comparison does not take into account the large accumulation of 18:1 $\omega 9$ observed in cryptomonad-fed krill. The major difference in our study between zooplankton- and phytoplankton-fed krill appeared to be in the levels of $18: 2 \omega 6$ in DG (respectively 4.4 to $5.1 \%$ and 1.5 to $4.3 \%$ total FA). Whilst carnivory was detectable based on this criterion, FA profiles alone did not provide sufficient clues to the zooplankton species preyed on and the nature of phytoplankton ingested by prey. Whilst not examined in this study, the potential use of other signature lipids, such as sterols, to examine the extent of carnivory is likely to be worthy of further research.

In the field, Antarctic krill prey on copepods (Huntley et al. 1994, Atkinson \& Snÿder 1997, Perissinotto et al. 2000, Atkinson et al. 2002). Nevertheless, recent research has shown that typical components of copepod lipids, such as 20:1 and 22:1 FA and alcohols, are not incorporated into Euphausia superba lipids (Phleger et al. 1998, Hagen et al. 2001, Stübing et al. 2003). These authors concluded that the dietary signature of copepods in krill lipids might be rather small. Unfortunately, no source of Antarctic copepods was available to be used as prey in our experiments, so this remains to be confirmed by analysis of DG from copepod-fed krill.

Carnivory may play a dominant role when primary production is low, i.e. at times of the year when the metabolism of organisms should not prioritise lipid deposition. In support of this hypothesis, comparison of feeding rates with lipid accumulation in the krill DG suggests decreasing nutritional value from phytoplankton (cryptomonads being the most favourable diet, followed by diatoms) to zooplankton. 


\section{CONCLUSIONS}

Our results support earlier findings that the influence of diet on lipid class and FA compositions in the whole body of juvenile Euphausia superba is weak. However, we show that lipids in digestive glands may be used as trophic markers to study trophic relationships of krill in the Antarctic plankton community. The interpretation of FA signatures is not as simplistic as initially believed though, and some caution is needed when applying the approach to complex marine systems. FA profiles that reflect feeding on particular algal groups might not necessarily closely resemble the FA composition of the consumed algae. This is because some FA that are abundant in the food might not be accumulated in krill, while some others that are minor or absent in the diet might accumulate from alternative source (biosynthesis, retroconversion). This is why no FA on its own should be considered as a signature. FA signatures are multivariate and require several dietary markers to be validated.

Acknowledgements. We thank P. Cramp, R. King, B. Mooney and Dr. J. P. Labat for their helpful assistance. La Fondation Singer-Polignac (Paris), Le Ministère des Affaires Etrangères (Lavoisier fellowship), the Australian Antarctic Division and the Australian Research Council supported this project. Our thanks go to the captain and crew of the RV 'Aurora Australis' for their assistance during sampling. We are very grateful to A. and J. Briolay for their generous support and to 4 anonymous referees for their helpful comments on this manuscript.

\section{LITERATURE CITED}

Alonzo F, Nicol S, Virtue P, Nichols P (2003) Lipids as trophic markers in Antarctic krill. I. Validation under controlled laboratory conditions. In: Huiskes AHL, Gieskes WWC, Rozema J, Schorno RML, van der Vies SM, Wolff WJ (eds) Antarctic biology in a global context. Backhuys Publishers, Leiden, p 121-128

Alonzo F, Virtue P, Nicol S, Nichols PD (2005) Lipids as trophic markers in Antarctic krill. III. Temporal changes in digestive gland lipid composition of Euphausia superba in controlled conditions. Mar Ecol Prog Ser 296:81-91

Antezana T, Ray K, Melo C (1982) Trophic behaviour of Euphausia superba Dana in laboratory conditions. Polar Biol 1:77-82

Atkinson A, Snÿder R (1997) Krill-copepod interactions at South Georgia, Antarctica. I. Omnivory by Euphausia superba. Mar Ecol Prog Ser 160:63-76

Atkinson A, Meyer B, Stübing D, Hagen W, Schmidt K, Bathmann UV (2002) Feeding and energy budgets of Antarctic krill Euphausia superba at the onset of winter. II. Juveniles and adults. Limnol Oceanogr 47:953-966

Bahnweg G, Sparrow FK (1974) Four new species of thraustochytrium from Antarctic regions with notes on the distribution of zoosporic fungi in the Antarctic ecosystems. Am J Bot 61:754-766

Bakes MJ, Elliott NG, Green GJ, Nichols PD (1995) Variation in lipid composition of some deep-sea fish (Teleostei: Oreosomatidae and Trachichthyidae). Comp Biochem Physiol B 111:633-642
Bligh EG, Dyer WM (1959) A rapid method of total lipid extraction and purification. Can J Biochem Physiol 35:911-917

Bottino NR (1974) The fatty acids of Antarctic phytoplankton and euphausiids: fatty acid exchange among trophic levels of the Ross Sea. Mar Biol 27:197-204

Clarke A (1980) The biochemical composition of krill Euphausia superba Dana from South Georgia. J Exp Mar Biol Ecol 43:221-236

Cripps GC, Atkinson A (2000) Fatty acid composition as an indicator of carnivory in Antarctic krill, Euphausia superba. Can J Fish Aquat Sci 57(Suppl 3):31-37

Cripps GC, Hill HJ (1998) Changes in lipid composition of copepods and Euphausia superba associated with diet and environmental conditions at the marginal ice zone. DeepSea Res Part I 45:1357-1381

Cripps GC, Watkins JL, Hill HJ, Atkinson A (1999) Fatty acid content of Antarctic krill Euphausia superba at South Georgia related to regional populations and variations in diet. Mar Ecol Prog Ser 181:177-188

Dall W, Chandumpai A, Smith DM (1992) Fatty acid composition of organs and tissues of the tiger prawn Penaeus esculentus during the moulting cycle and during starvation. Mar Biol 113:45-55

Dalsgaard J, St. John M, Kattner G, Müller-Navarra D, Hagen W (2003) Fatty acid trophic markers in the pelagic marine environment. Adv Mar Biol 46:225-340

Dunstan GA, Volkman JK, Barret SM, Leroi JM, Jeffrey SW (1994) Essential polyunsaturated fatty acids from 14 species of diatom (Bacillariophyceae). Phytochemistry 35: 155-161

El-Sayed SZ (1985) Plankton of the Antarctic seas. In: Bonner WN, Walton DWH (eds) Key environments-Antarctica. Pergamon Press, Oxford, p 135-155

Falk-Petersen S, Hopkins CCE, Sargent JR (1990) Trophic relationships in the pelagic arctic food web. In: Barnes $M$, Gibson RN (eds) Trophic relationships in the marine environment: Proc 24th Eur Mar Biol Symp. Aberdeen University Press, Aberdeen, p 315-333

Falk-Petersen S, Hagen W, Kattner G, Clarke A, Sargent JR (2000) Lipids, trophic relationships, and biodiversity in Arctic and Antarctic krill. Can J Fish Aquat Sci 57:178-191

Frazer TK (1996) Stable isotopes $(\delta 13 \mathrm{C}$ and $\delta 15 \mathrm{~N})$ of larval krill, Euphausia superba, and two of its potential food resources in winter. J Plankton Res 18:1413-1426

Frost BW (1972) Effects of size and concentration of food particles on the feeding behaviour of the marine planktonic copepod Calanus pacificus. Limnol Oceanogr 17:805-815

Graeve M, Kattner G, Hagen W (1994) Diet-induced changes in the fatty acid composition of arctic herbivorous copepods: experimental evidence of trophic markers. J Exp Mar Biol Ecol 182:97-110

Guillard RRL, Ryther JH (1962) Studies in the marine planktonic diatoms. I. Cyclotella nana (Hustedt) and Detonula confervacea (Cleve) Gran. Can J Microbiol 8:229-239

Hagen W, Kattner G, Terbrüggen A, Van Vleet ES (2001) Lipid metabolism of the Antarctic krill Euphausia superba and its ecological implications. Mar Biol 139:95-104

Håkanson JL (1984) The long and short term feeding condition in field-caught Calanus pacificus, as determined from the lipid content. Limnol Oceanogr 29:794-804

Hernandez-León S, Portillo-Hahnefeld A, Almeida C, Bécognée $\mathrm{P}$, Moreno I (2001) Diel feeding behaviour of krill in the Gerlache Strait, Antarctica. Mar Ecol Prog Ser 223:235-242

Hopkins TL, Ainley DG, Torres JJ, Lancraft TM (1993) Trophic structure in open waters of the marginal ice zone in the Scotia-Weddell confluence region during spring 1983. Polar Biol 13:389-397 
Huntley ME, Nordhausen W, Lopez MDG (1994) Elemental composition, metabolic activity and growth of Antarctic krill Euphausia superba during winter. Mar Ecol Prog Ser 107:23-40

Kils U (1981) Swimming behaviour, swimming performance and energy balance of Antarctic krill Euphausia superba. BIOMASS Sci Ser 3:1-122

Kolokowska A (1991) The influence of sex and maturity stage of krill (Euphausia superba Dana) upon the content and composition of its lipids. Polar Res 12:73-78

Lee RF, Nevenzel JC, Paffenhöffer GA (1971) Importance of the wax-esters and other lipids in the marine food-chain: phytoplankton and copepods. Mar Biol 9:99-108

Lewis TE, Nichols PD, McMeekin TA (1999) The biotechnological potential of thraustochytrids. Mar Biotechnol 1: 580-587

Mayzaud P (1997) Spatial and life cycle changes in lipid and fatty acid structure of the Antarctic euphausiid Euphausia superba. In: Battaglia B, Valencia J, Walton DH (eds) Antarctic communities: species, structure and survival. Cambridge University Press, Cambridge, p 284-294

Mayzaud P, Eaton CA, Ackman RG (1976) The occurrence and distribution of octadecapentaenoic acid in a natural plankton population: a possible food chain index. Lipids 11:858-862

Mayzaud P, Albessard, E, Cuzin-Roudy J (1998) Changes in lipid composition of the Antarctic krill Euphausia superba in the Indian sector of the Antarctic Ocean: influence of geographical location, sexual maturity stage and distribution among organs. Mar Ecol Prog Ser 173:149-162

Miller DGM, Hampton I (1989) The biology and ecology of the Antarctic krill (Euphausia superba Dana): a review. BIOMASS Sci Ser 9:1-166

Nelson MM, Phleger CF, Mooney BD, Nichols PD (2000) Lipids in gelatinous Antarctic zooplankton: Cnidaria and Ctenophora. Lipids 35:551-559

Nemoto T (1967) Feeding patterns of euphausiids and differentiations in their body characters. Info Bull Planktol Soc Japan Commem Iss No. 61:157-174

Nichols PD, Bakes MJ, Elliott NG (1998) Docosahexanoic acid-rich liver oils from temperate Australian sharks. Mar Freshw Res 49:763-767

Pakhomov EA, Perissinotto R, Froneman PW, Miller DGM (1997) Energetics and feeding dynamics of Euphausia superba in the South Georgia region during the summer of 1994. J Plankton Res 19:399-423

Perissinotto R, Pakhomov EA, McQuaid CD, Froneman PW (1997) In situ grazing rates and daily ration of Antarctic krill Euphausia superba feeding on phytoplankton at the Antarctic Polar Front and the Marginal Ice Zone. Mar Ecol Prog Ser 160:77-91

Perissinotto R, Gurney L, Pakhomov EA (2000) Contribution of heterotrophic material to diet and energy budget of Antarctic krill, Euphausia superba. Mar Biol 136:129-135

Phleger CF, Nichols PD, Virtue P (1998) Lipids and trophodynamics of Antarctic zooplankton. Comp Biochem Physiol B 120:311-323

Phleger CF, Nelson MM, Mooney BD, Nichols PD (2002) Interannual and between species comparison of the lipids, fatty acids and sterols of Antarctic krill from the US AMLR Elephant Island survey area. Comp Biochem Physiol B 131:733-747

Pond D, Watkins J, Priddle J, Sargent JR (1995) Variation in the lipid content and composition of Antarctic krill Euphausia superba at South Georgia. Mar Ecol Prog Ser $117: 49-57$

Price HJ, Boyd KR, Boyd CM (1988) Omnivorous feeding behavior of the Antarctic krill Euphausia superba. Mar Biol 97:67-77

Quetin LB, Ross RM, Clarke A (1994) Krill energetics: seasonal and environmental aspects of the physiology of Euphausia superba. In: El-Sayed SZ (ed) Southern Ocean ecology, the BIOMASS prospective. Cambridge University Press, Cambridge, p 165-184

Ross RM, Quetin LB (1988) Euphausia superba: a critical review of annual production. Comp Biochem Physiol 90B:499-505

Sargent JR, Henderson RJ (1995) Marine (n-3)polyunsaturated fatty acids. In: Hamilton RJ (ed) Developments in oils and fats. Blackie Academic and Professional, Glasgow, p 32-65

Sargent JR, Eilersten HC, Falk-Petersen S, Taasen JP (1985) Carbon assimilation and lipid production in phytoplankton in northern Norwegian fjords. Mar Biol 5:109-116

Sargent JR, Parkes RJ, Mueller-Harvey I, Henderson RJ (1987) Lipid biomarkers in marine ecology. In: Sleigh MA (ed) Microbes in the sea. Ellis Horwood, Chichester, p 119-138

Schnack SB (1985) Feeding by Euphausia superba and copepod species in response to varying concentrations of phytoplankton. In: Siegfried WR, Condy PR, Laws RM (eds) Antarctic nutrient cycles and food webs. SpringerVerlag, Heidelberg, p 311-323

Sokal RR, Rohlf FJ (1981) Biometry, 2nd edn. WH Freeman, San Francisco, CA

Stübing D, Hagen W (2003) Fatty acid biomarker ratiossuitable trophic indicators in Antarctic euphausiids? Polar Biol 26:774-782

Stübing D, Hagen W, Schmidt K (2003) On the use of lipid biomarkers in marine food web analyses: an experimental case study on the Antarctic krill, Euphausia superba. Limnol Oceanogr 48:1685-1700

Teshima S, Kanazawa A (1980) Transport of dietary lipids and role of serum lipoproteins in the prawn. Bull Jpn Soc Sci Fish 46:51-55

Thomson PG, Wright SW, Bolch CJS, Nichols PD, Skerrat JH, McMinn A (2004) Antarctic distribution, pigment and lipid composition, and molecular identification of the brine dinoflagellate Polarella glacialis (Dinophyceae). J Phycol 40:867-873

Torres JJ, Donnelly J, Hopkins TL, Lancraft TM, Aarset AV, Ainley DG (1994) Proximate composition and overwintering strategies of Antarctic micronektonic Crustacea. Mar Ecol Prog Ser 113:221-232

Virtue P, Nicol S, Nichols PD (1993a) Changes in the digestive gland of Euphausia superba during short-term starvation: lipid class, fatty acid and sterol content and composition. Mar Biol 117:441-448

Virtue P, Nichols PD, Nicol S, McMinn A, Sikes EL (1993b) The lipid composition of Euphausia superba Dana in relation to the nutritional value of Pheaocystis poucheti (Hariot) Lagerheim. Antarct Sci 5:169-177

Virtue P, Nichols PD, Nicol S, Hosie G (1996) Reproductive trade off in male Antarctic krill. Mar Biol 126:521-527

Virtue P, Nichols PD, Nicol S (1997) Dietary-related mechanisms of survival in Euphausia superba: biochemical changes during long-term starvation and bacteria as a possible source of nutrition. In: Battaglia B, Valencia J, Walton DH (eds) Antarctic communities: species, structure and survival. Cambridge University Press, Cambridge, p 193-201

Volkman JK, Jeffrey SW, Nichols PD, Rogers GI, Garland CD (1989) Fatty acid composition of 10 species of microalgae used in mariculture. J Exp Mar Biol Ecol 128:219-240

Wold S (1987) Principal component analysis. Chenometr Intell Lab 2:37-52

Submitted: November 20, 2003; Accepted: September 30, 2004 Proofs received from author(s): June 2, 2005 